\title{
A Typological Overview of Relative Clause Structure in Mesoamerican Languages
}

\author{
Enrique L. Palancar \\ Roberto Zavala Maldonado \\ Claudine Chamoreau
}

\begin{abstract}
In this chapter, we identify what constitutes the canonical profile of relative constructions in the Mesoamerican languages. We propose that the typical Mesoamerican relative clause is a morphosyntactic finite relative clause with a gap, but when the relativized position is that of locative, a relative pronoun is typically used (with this pattern reaching out beyond Mesoamerica). In our proposal, we have identified three structural traits that we take to be Mesoamerican: (i) relative clauses introduced by determiners which agree in deixis with the determiner of the DP in which the domain nominal of the relative clause is embedded; (ii) the so-called 'pied-piping with inversion' introduced by Smith-Stark (1988) for interrogatives that has percolated into relative clause structure; and (iii) headless relative clauses with a gap, that is, headless relative clauses where there is little indication as to the role of the relativized element.
\end{abstract}




\title{
A Typological Overview of Relative Clause Structure in Mesoamerican Languages
}

\author{
Enrique L. Palancar \\ Roberto Zavala Maldonado \\ Claudine Chamoreau
}

\subsection{Introduction}

The goal of this chapter is to introduce a number of relevant aspects concerning relative clause (RC) structures in Mesoamerican languages. The aspects that we discuss here are aimed at providing a better understanding of what constitutes the Mesoamerican linguistic area as introduced in Campbell et al. (1986). We present an overview of the wide range of possible RC structures that we have observed through the study of RC structures in a broad sample of Mesoamerican language families. We concentrate on aspects of clausal syntax as well as phenomena at the morphology-syntax interface. We do not give examples from all families here, only from a selected set of languages that we believe serve as illustrations of the relevant constructions. This perspective establishes what is structurally expected in the RCS of a Mesoamerican language, and thus provides a reference point to understand the typological relevance of other possible phenomena that stray from the structures that we discuss in this chapter.

The typical RC in a language of Mesoamerica is a morphosyntactic finite RC - this fact holds to the extent that no language in the area has non-finite RCs. We discuss this trait in $\S 1.2$. The typical RC has a gap. Asyndetic RCs (i.e., those not introduced by a conjunction) are also very common in the area, although they are by no means exclusive to the area or present in all languages. Similarly, having a locative pronoun as the only manifestation of the relative pronoun strategy is typically Mesoamerican; we discuss this in §1.4.2. Aside from the commonality of certain patterns, there are at least three structural traits that appear to be uniquely Mesoamerican: (i) RCS introduced by determiners which agree in deixis with the determiner of the DP in which the domain nominal of the RC is embedded (we discuss this trait in depth in \$1.4.1.1); (ii) so-called 'pied-piping with inversion' introduced by Smith-Stark (1988) for interrogatives that has percolated into RC structure (discussed in §1.5.1); and (iii) headless RCs with a gap (covered in §1.6.3).

This chapter is divided in five sections. In $\$ 2$, we discuss the finiteness of RCS in Mesoamerican languages. In $\S 1.3$ we tackle a number of phenomena relevant to the wordorder position of the RC in headed RC constructions. In $\$ 1.4$, we deal with the different ways in which the domain nominal in headed RC constructions is realized in the RC. In $\S 1.5$, we revisit the correlations that exist between relativization strategy and the relativization hierarchy. Sections 1.2-1.5 deal with RCs headed by a full nominal. In $\$ 1.6$, we introduce some relevant constructions that involve other types of heads, from null-nominal to fully headless RCs. The chapter concludes in §1.7.

\subsection{Finiteness and Nominalization}


In all Mesoamerican languages, RCS are finite both morphologically and syntactically. A typical example of this is the headed RC in Texistepec Popoluca (Gulf Zoquean; MixeZoquean) in (1). Here the RC (in brackets) is postnominal, it is headed by the noun pelota 'ball' (in italics) and it is introduced by a relativizer that occurs as a second position clitic. The predicate in the RC is finite because the verb is inflected for person of core arguments and for TAM. ${ }^{1}$

TeXISTEPEC Popoluca (MIXe-ZoQueAN)

...byatin kyet pelota ma'pi' wiipke'm

$$
\begin{aligned}
& y \text {-batin y-ket pelota }\left[\boldsymbol{m a}^{\prime}=p \dot{t}^{\prime} \quad \boldsymbol{y}\right. \text {-wêêp-kê'm] } \\
& \text { A3-hear S3D-fall ball [PFV=REL A3-throw-go.up] }
\end{aligned}
$$

'... He heard the falling of the ball that he had thrown.' $\{$ Txt $\}$

(Díez Alejandre 2019: 29; apud Wichmann 1996: 159)

Broadly speaking, the correlation between finiteness and RC structure can be taken to be a Mesoamerican trait. Beyond the borders of Mesoamerica to the North, languages treat RCS as nominalizations in many respects. A typical case is Yaqui, a Uto-Aztecan language of northern Mexico, as illustrated in (2). Here the nominalization of a RC can be observed at both an internal and external level, and at both a morphological and syntactic level. Internally, as is common in languages with RC nominalizations, there is distinct nominalizing morphology associated with the predicate of the RC to indicate subject vs. object relativization: in (2a) $-m$ marks subject relativization, whereas -' $u$ in (2b) marks object relativization. Furthermore, as shown in (2b), the notional subject in the RC is encoded with a genitive phrase or a possessive instead of a nominative. Externally, the RC agrees in case $(2 a)$ or in number (2b) with the head noun.

YAQUI (UTO-AZTECAN)

(2) a. Joan uka chu'u-ta [Maria-ta ke'e-ka-m]-ta me'a-k John DET.ACC dog-ACC Mary-ACC bite-PFV-S.REL-ACC kill-PFV 'John killed the dog that bit Mary.'

(Álvarez González 2012: 72)
b. u-me bisikleeta-m [in jinu-ka-'u]-m sikili DET-PL bicycle-PL GEN1SG buy-PFV-O.REL-PL red 'The bicycles that I bought are red.'

(Álvarez González 2012: 73)

Further evidence that finite RCS constitute a Mesoamerican trait comes from the fact that, while nominalization is common among the Northern Uto-Aztecan languages, the UtoAztecan languages found in the Mesoamerican area exhibit finite RCs. For instance, this can be seen in Cora, as shown in (3). Here a RC is not introduced by any linker, but a special set of pronouns that agree in person/number with the subject of the subordinate clause (i.e.,

\footnotetext{
${ }^{1}$ Whenever the sources make possible, we use examples that come from texts. Textual examples are indicated by $\{T x t\}$. When two or more examples from the same source are given under the same example number, we only indicate the source in the last example.
} 
the equivalent pronoun for 3SG subject in a matrix clause would have been pu; but see $\S 1.4 .1 .2$ for more on the nature on these pronouns).

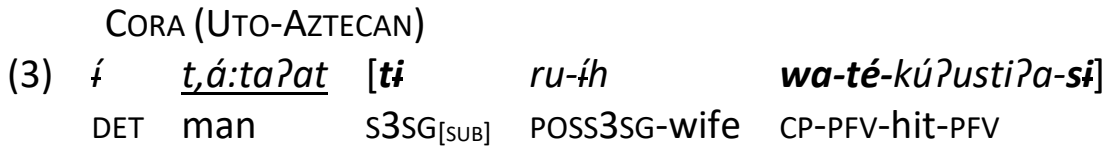

'The man who hit his wife.'

(Vázquez Soto 2002: 299)

Towards the south of the Mesoamerican area, languages start having traits of nominalization again in RC structure. Pesh, a Chibchan language, has RCs with finite predicates and syntax, but the clauses themselves are treated externally as syntactic nominals, because they can receive nominal case. This is shown in (4) where the comitative/instrumental case enclitic $=y o$ occurs at the right edge of the RC to mark the role of a relativized instrument. Note that in (4) the domain nominal is the object of the matrix predicate.

PESH (CHIBCHAN)

(4) kúkàrskà yè?há tàkiíyó úhàrí

\begin{tabular}{|c|c|c|c|}
\hline kukarska & [ye?-ha & ta-ka- $\varnothing-i]=$ yo & $\varnothing$-uh-a-ri \\
\hline & small-NMLZ & O1-hit-S3SG-PST=INSTR & O3sG-hide-s1sG-PST \\
\hline
\end{tabular}

(Chamoreau this volume)

Further south from the Mesoamerican area, in Central America, the typical syntax of relativization starts looking much like the nominalizations in the languages of northern Mexico. This again confirms that the finiteness of RCs in the Mesoamerican geographical area is a typical areal characteristic. In the following sections, from $\S 1.3$ to $\S 1.5$, we study various aspects of the syntax of headed RCs. We turn to headless RCs in $\S 1.6$.

\subsection{Word Order}

To illustrate word order as it relates to RC structure, we can start by first considering the RC construction in (5) from Kaqchikel (K'ichean; Mayan).

KAQCHIKEL (MAYAN)

(5) kan $n-\varnothing$-a-k'oxa-j ri ri wnäq [y-e-sewö] INTERJ ICP-O3SG-A2SG-listen-TR DEM DEF person ICP-S3PL-breathe

'You can hear very clearly those people who are breathing.' $\{$ Txt $\}$

(Guarcax González 2016: 101)

Example (5) is an instance of a headed RC construction and shows typical traits of the type of construction that we find in other languages in the Mesoamerican area. Let us first concentrate on the relative order of the RC with respect to the domain nominal. The domain nominal in (5) is wnäq 'people', which appears in the NP that functions as the object of the 
main clause. The RC yesewö 'who are breathing' follows the head noun, so here we have a postnominal RC.

Kaqchikel, as is typical of Mayan languages, is a verb-initial language. For this language, having postnominal RCS is consistent with the implicative word order correlation of a V-initial language (Dryer 2007). ${ }^{2}$ All Mesoamerican languages, except Mixe-Zoquean, are $\mathrm{V}$-initial and in most of them we also find postnominal RCs. Zoquean languages display structures that reveal traces of having historically had a V-final word order. Some of them, like Santa María Chimalapa Zoque (Oaxaca Zoquean; Mixe-Zoquean), still have a predominant V-final order. In all such languages, we also find examples of prenominal RCs. The examples in (6) from San Miguel Chimalapa Zoque show a prenominal and a postnominal RC in two matrix clauses with V-final order, respectively. Here the RCS are introduced by a relativizer (i.e., a subordinator that only introduces a RC), but interestingly there are two distinct relativizers, one for each type of RC (see Jiménez this volume for further differences in prosody).

\section{San Miguel Chimalapa Zoque (Mixe-Zoquean)}

(6) a. tsijpa'k pin 'ty nukokmangxukki

$$
\begin{aligned}
& {\left[\varnothing=t s i j-p a=p \dot{t}^{\prime} k\right] \quad \text { pin } \quad ' \dot{t y}=n u k \text {-'ok.mang-xuk-wí }} \\
& \text { S3.I=stone-ICP.I=REL man A3.I=grab-start-3PL-CP.I }
\end{aligned}
$$

'They started attacking the man that throws stones.' $\{$ Txt $\}$

(Jiménez this volume)

b. bi mi'a 'in niwaktammi' 'in pinik tikjonang

$$
\begin{array}{llll}
\text { bi } & \frac{m \dot{t}^{\prime} a}{\text { DET }} & \text { [PAUSE] } & {\left[{ }^{\prime}+n=n i w a k-t a m-w \dot{t}=p \dot{t}^{\prime}\right]} \\
\text { deer } & \text { A1.I=steal-PL.SAP-CP.I=REL }
\end{array}
$$

$$
\begin{array}{ll}
\text { 't } n=p \dot{k}-n \dot{*} k-w \dot{t} & t \dot{*}=\text { =jo=nang } \\
\text { A1.l }=\text { grab-go-CP.I } & \text { house=LOC=PERLOC }
\end{array}
$$

'The deer we stole (from the tiger) we brought it home.' $\{$ Txt $\}$

$$
\text { (Jiménez this volume) }
$$

Gulf Zoquean languages are V-initial, but they have retained prenominal Rcs only in specific circumstances, as illustrated in (7) from Texistepec Popoluca. Here the RCs are also introduced by the enclitic $=p i^{\prime} /=p u^{\prime}$, a cognate of San Miguel Chimalapa's $=p \dot{t}^{\prime}$ in (6b). In these languages, prenominal RCs are only used with intransitive predicates, where they are mainly used with stative predicates for the expression of property concepts, like in (7a). We also find prenominal RCs with the stative verb -'ech 'be located', like in (7b), and to construct agent nouns, like in (7c). Such prenominal RCs in Texistepec Popoluca can be contrasted with the postnominal RC in (1) above, which is the default type.

\footnotetext{
${ }^{2}$ Also characterized as Universal 107 from The Universals Archive at the University of Konstanz (based on Greenberg 1963): "Nominal modifiers (such as relative, adjectival, and attributive expressions) follow nouns in VO languages and precede nouns in OV languages" (<http://typo.uni-konstanz.de/archive>).
} 
TeXISTEPec Popoluca (Mixe-ZoQuean)
$\begin{array}{ccccc}\text { (7) a. 'entonse } m a^{\prime} & \varnothing \text {-nim } & {[\varnothing \text {-tiw-ki'da'a=pi'] }} & \frac{k a a \eta-d a^{\prime} a}{\text { tiger-AUG }} \\ \text { then } & \text { PFV } & \text { s3.l-say } & \text { s3.l-big-ADJ=REL } & \end{array}$
'Then the largest tiger said [...].' $\{T x t\}$

(Díez Alejandre 2019: 29; apud Wichmann 1993)

b. $\left[\varnothing-' e c h=p u^{\prime}\right.$ njem $]$ suutu'
S3.I-be=REL there young.man
'The young man who is over there.' $\{$ Txt $\}$

(Díez Alejandre 2019: 31; apud Wichmann 1993)

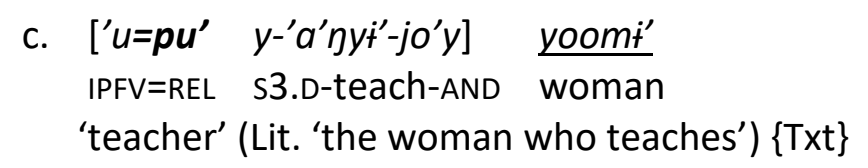

(Díez Alejandre 2019: 31; apud Wichmann 1993)

Prenominal RCS bring us to the phenomenon of the borrowing of RC syntax. The relativizers of the Mayan languages of the Cholan branch have been borrowed from some ancient Zoquean language. Chol has the relativizer $=b \dot{t}$, which is a cognate of Texistepecan $=p \dot{t}^{\prime}$ or San Miguel Chimalapa's $=p \dot{t}^{\prime}$. An example is given in (8) from Tila Chol, which additionally shows that in Chol, like in Kaqchikel in (5) above, the canonical RC is postnominal.
(8) tyi k-miñn-i- $\varnothing \quad \underline{\text { ixim }} \quad$ [chonkol=bi $\quad i-c h o \tilde{n}-\varnothing \quad$ li $\quad x$-ixik]
PFV A1-buy-TV-PO3 corn PRG=REL A3-sell-PO3 DET CLF-woman
'I bought the corn that the woman is selling.'

(Vázquez Álvarez 2011: 174)

The borrowing of a relativizer reveals intense language contact between some form of proto-Cholan and some branch of proto-Zoquean. But the impact of language contact on RC structure goes beyond the word and involves RC syntax too, because Chontal and Chol (both belonging to the Cholan branch) are the only two Mayan languages that can also have prenominal RCs. In Tabasco Chontal, like in the Gulf branch of Zoquean, the use of such prenominal clauses is mainly restricted to the expression of property concepts by means of intransitive stative predicates. Prenominal RCS are also highly integrated into the phrasal syntax of the domain nominal. This can be seen in the Chol example in (9), where the determiner of the DP occurs to the left of the RC that precedes the domain nominal. ${ }^{3}$

\footnotetext{
3 Prenominal RCS are apparently also allowed with other intransitive predicates, but none of the sources (Martínez Cruz 2007; Vázquez Álvarez 2011; Vázquez Álvarez \& Coon 2021) give actual examples from texts, so their degree of naturalness is uncertain. As for transitive clauses, authors do not agree; for Martínez Cruz (2007) they are possible, but for Vázquez Álvarez \& Coon (2021) they are not.
} 
CHOL (MAYAN)
(9) che' bajche ixi $\quad\left[p^{\prime} e l-e l-\varnothing=i x=b \dot{+}\right] \quad$ tye' $=i$
so like DEM saw-TS-S3=already=REL wood $=\mathrm{CL}$
'They are like those pieces of wood that are already sawn.'

(Martínez Cruz 2007: 35)

Apart from the relativizer and prenominal RCs, Chol shows yet another trait in common with Gulf and Chiapas Zoquean languages: the fact that the relativizer is a second-position clitic. Cholan languages borrowed their RC syntax from Chiapas Zoquean. The structural commonalities involving RCs between different language families - as attested in Cholan, and Gulf and Chiapas Zoquean - provides evidence for two important facts which explain the commonalities we find among the RC constructions in different languages of Mesoamerica: (i) the syntax of RCS can indeed be borrowed; and (ii) RC syntax was indeed borrowed in historical times by the different linguistic communities sharing Mesoamerican culture in the Mesoamerica geographic area.

Further evidence that (i) and (ii) have happened in more recent times is borne out by the fact that some languages of the area have borrowed relative pronouns from Spanish, like in San Miguel Chimalapa Zoque, whose locative relative pronoun donde is from Spanish donde 'where', as shown in (10a), which is sometimes used in combination with native $j u$, as shown in (10b).

San Miguel Chimalapa Zoque (Mixe-Zoquean)

(10) a. 'axta gaja donde tijawi bi 'eskwela

$\begin{array}{lllll}\text { 'axta } \frac{k a=j a}{\text { [donde }} \varnothing=t+j-' a-w \dot{t} & \text { bi } & \text { 'eskwela] } \\ \text { up_to DIST=LOC } & \text { WHERE } & \text { S3.I=exist-INCH-CP.I } & \text { DET } & \text { school } \\ \text { 'Right up to there where the school is.' }\{\text { Txt }\} & & \end{array}$

(Jiménez 2014: 307, 308)

b. '’y nikwakxuk(ki) gaj(a) donju tejidam(mi)

$\begin{array}{llll}\text { 'ty } y=n i k-w a k-x u k-W i & k a=j a & {[\text { don=ju }} & \emptyset=\text { teji-tam-Wi] } \\ \text { A3=body-break-3PL-CP.I } & \text { DIST=LOC } & \text { WHERE=WHERE } & \text { s1.I=exist-PL.SAP-CP.I }\end{array}$

'They asaulted him over there where we were.' $\{$ Txt $\}$

(Jiménez 2014: 307, 308)

Similarly, Sierra Popoluca, a Gulf Zoquean language, has borrowed the subordinator Piga in (11a) from a Gulf variety of Nahuatl, but has extended its use to cover RCs, like in (11b). In Gulf varieties of Nahuatl, iga introduces complement clauses, as shown in (12) from Pajapan Nahuat. However, to introduce a RC the language uses another subordinator (see the discussion around examples (71-72) below in Section 1.5.2, and Section 1.4.1.1 for the categorical distinction we make between subordinator, complementizer and relativizer).

Sierra Popoluca (Mixe-ZoQuean)

(11) a. Piríxtyim Piga itch dya Panhjo?yká?

$\begin{array}{llll}\text { Pi-Píx-W-tyi-Pam } & \text { Piga=Pich } & d y a & \text { Pan-jo?y_kaP-W } \\ \text { A3-see-CP-just-already } & \text { SUB }=1_{\text {PRO }} & \text { NEG } & \text { A1PL.EXCL-be.angry-CP }\end{array}$

'He saw that I wasn't angry.' $\{$ Txt $\}$

(Boudreault 2009: 596) 
b. miny je?m tzu ?saawa ?iga?ipa?kpa mok

\begin{tabular}{|c|c|c|c|}
\hline$\varnothing=\min -w \dot{t}$ & je?m & tzu?u-saawa & {$[$ Piga $=$ ?i=pa?k-pa } \\
\hline s3=come-cP & DEF & night-wind & $S U B=A 3=$ hit $-I C P$ \\
\hline
\end{tabular}

(López 2021: 485)

PAJAPAN NAHUAT (UTO-AZTECAN)

$\begin{array}{lllll}\text { (12) a. } & \varnothing \text {-neh-ihli:-keh } & \text { iga } & \text { ti-k-bi-skiya } & \text { mo-tomin } \\ \text { s3-PO1-tell.PFV-PL } & \text { COMP } & \text { s2-PO3-take-cond } & \text { POSs2-money }\end{array}$ 'They told me that you want your money.'

(Peralta Ramírez 2017)

b. nemi $\varnothing$-cho:ga ho:n tago-tzin [yeh ti-k-ma:-chaloh] PRG S3-cry DEM.SG girl-DIM SUB s2-PO3-hand-hit.PFV 'The girl you hit on her hand is crying.'

(Peralta Ramírez 2017)

We can establish that the canonical RC in a Mesoamerican language is postnominal. We find this situation by default, unless the language shows traces of V-final word order, like the conservative Mixe-Zoquean languages. Postnominal RCS are also the expected trait in Vinitial languages. But note that postnominal RC syntax is also found to the south beyond Mesoamerica. For example, Pesh, a Chibchan language from Honduras outside the cultural area of Mesoamerica, is a V-final language with postnominal RCs, as shown in (13). But this trait cannot be attributed to a Mesoamerican influence, since postnominal and prenominal orders are about equally common among V-final languages (Dryer 2007: 97).

PESH (CHIBCHAN)

árwã́ kápà fífkáwáyó kàkòrstá

arwã $[k a p a f-i f-k-a-w a]=$ yo

$\varnothing$-ka-kors-t-a-wa

man speak-DES-?-S1SG-PRS=COM/INSTR O3SG-APPL:R-Write-DUR-S1SG-PFV

'I write to the man with whom I want to speak.' $\{$ Txt $\}$

(Chamoreau this volume)

In general, the position of the RC with respect to the head can be used as a good test for the degree of syntactic configurationality of the language in question. For instance, in Tlaxcala Nahuatl (Nahuan; Uto-Aztecan), a language argued by Flores Nájera (this volume) to have a great deal of non-configurational syntax, RCs can be postnominal, like in (14a), prenominal like (14b), or even extraposed with respect to the matrix clause and the constituent encoding the domain nominal, like in (14c).

TLaxcala nahuatl (Uto-Aztecan)

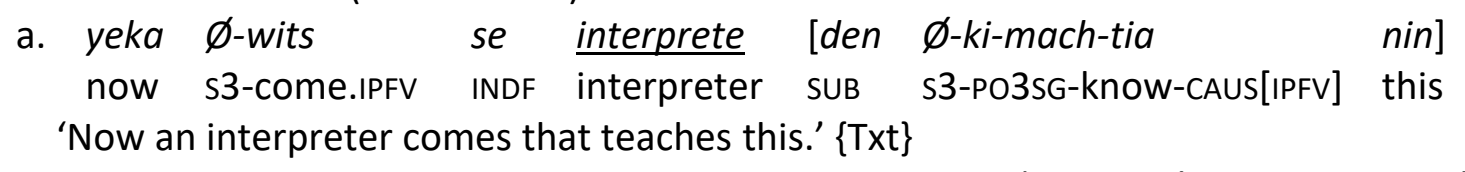

(Flores Nájera this volume)
b. [den $\varnothing$-nen-chikawa-k]
in kiawi-tl $\varnothing$-wits 
SUB S3-much-fortify-ST[IPFV] DEF rain-ABS S3-come.IPFV

'Rain comes that is fierce.' $\{$ Txt $\}$

(Flores Nájera this volume)

c. kox in onwito sirbe [den o-ti-k-walika-keh]?

perhaps DEF mushroom be.useful[s3] SUB PST-S1PL-PO3SG-bring.PFV-PL

'Does the little mushroom we brought with us perhaps work? \{Txt\}

(Flores Nájera this volume)

In contrast, languages with $\mathrm{V}$-final traits and with predominantly configurational syntax tend to have RCs that are extraposed. This is the case with Mixean languages like Tamazulápam Mixe (Mixean; Mixe-Zoquean), where all headed RCS, like any other subordinate clause, occur extraposed at the right edge of the matrix clause (see Zavala Maldonado this volume). This is illustrated in (15a) and contrasted with the ungrammaticality of (15b); in (15b), the RC is prenominal, but postnominal RCS are also ungrammatical.

TAMAZULÁPAM Mixe (MIXe-ZOQUEAN)

(15) a. ka't ëjts jä'äy ntseky mte'p jajp tsënnaatyëp

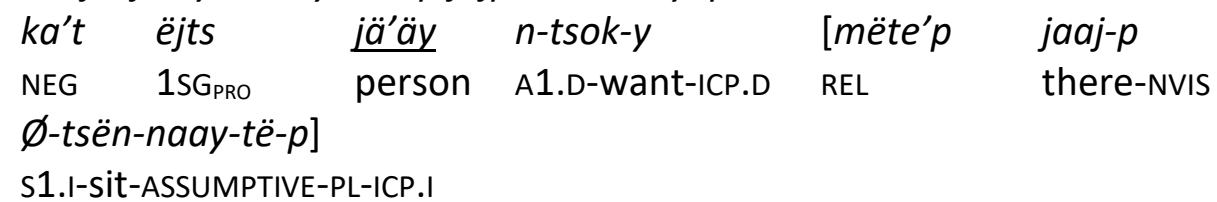

'I don't want those people that live over there.'

(Lit. 'I those people don't want, that live over there.')

(Santiago Martínez 2015: 83)

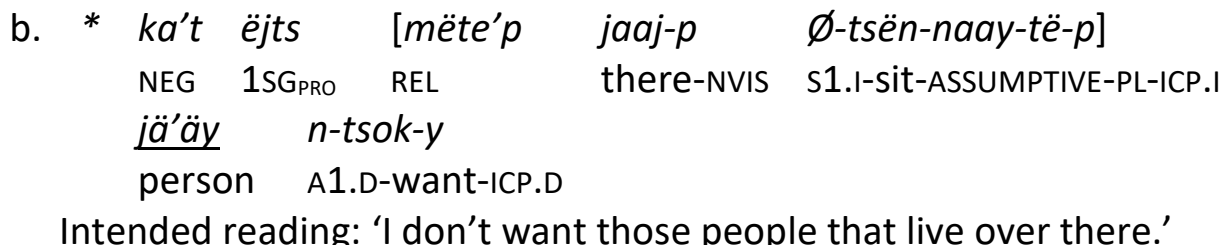

(Santiago Martínez 2015: 83)

A similar situation is found in Cora (Corachol; Uto-Aztecan) as illustrated in (16a). A postnominal RC is only found in Cora when the head appears in a syntactic phrase that has itself been extraposed to the right, as an elaboration of the referents already introduced in the matrix clause, like in (16b). However, nothing in the syntax of instances like (16b) assures us that the $\mathrm{RC}$ is really integrated in the DP encoding the domain nominal.

CORA (UTO-AZTECAN)

(16) a. kú:kupu pu wa-mípł [ti $m^{w} a$-čéih $]$ viper S3SG CP-die.SG S3SG[suB] O2sG-bite.PST

'The viper that bit you died.'

(Lit. 'The viper died, that bit you.')

(Vázquez Soto 2002: 317)

b. wa-mípi $\quad \dot{\text { kú:kupu }}\left[\begin{array}{l}t \dot{ } \quad m^{w} a-c ̌ e ́ i h\end{array}\right]$ 


$$
\text { [S3SG]CP-die.SG DET viper S3SG[suB] O2sG-bite.PST }
$$

'It died, the viper that bit you.'

(Vázquez Soto 2002: 317)

\subsection{The Realization of the Domain Nominal in the Relative Clause}

\subsubsection{The Gap Strategy}

The most common relativization strategy in the languages of Mesoamerica is the gap strategy, where there is no realization of the domain nominal within the RC. The examples in (17-19) illustrate this in different languages from different families: Mixe-Zoquean, Mayan and Oto-Pamean. The gap for the domain nominal is indicated by an underscore '_ ', which is located in the position in the RC where the domain nominal is most likely to have occurred, had the RC been a matrix clause.

OCOTEPEC ZOQue (MiXe-ZOQUeAN)

(17) te' yi'kida'mbi pit masundena'ajk musoyajpabi

$$
\begin{aligned}
& t e^{\prime} \quad\left[\quad \varnothing-y \dot{t}^{\prime}=k i=t a^{\prime} m=p \dot{i}^{\prime}\right] \quad \underline{p i n} \\
& \text { DET } \quad \mathrm{S} 3-\mathrm{PROX}=\mathrm{EXT} . \mathrm{LOC}=\mathrm{PL}=\mathrm{REL} \quad \operatorname{man}
\end{aligned}
$$

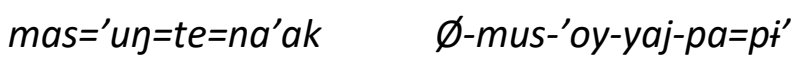

$$
\begin{aligned}
& \text { more }=R E P=C O P=C O N T R \quad S 3-k n O W-A P-P L 3-C P=R E L
\end{aligned}
$$

'The men who were from here they say they were the wisest.' $\{T x t\}$

(de la Cruz Morales 2016: 113)

TSELtAL (MAYAN)

(18) mach'a into te ermano [te y-ak'-oj-b-otik

who DEM DET brother SUB ${ }^{4}$ A3-send-PFV-APPL:R-PO1.INCL

tel - te jtatik Gabriel]?

DIR DET father G.

'Who is this brother that Father Gabriel sent to us?' $\{$ Txt $\}$

(Polian \& Aissen 2021: 411)

TILAPA ОTOMI (OTO-PAMEAN)

(19) tó 'öt'u='mbe ni nkü [ra kha=ni _ $]$

1.PFV paint.AS=PL.EXCL DEM.SG house [3]IPFV exist=there

'We painted the house that is over there.' $\{$ Txt $\}$

(Palancar this volume)

In the three RCS in (17-19) there is no trace of the domain nominal within the RC. They further instantiate two different types of RCS attending to the syntactic linking strategy they exhibit: (i) syndetic RCs, illustrated by (17 and 18), which are syntactically linked by means of an introductory element; and (ii) asyndetic RCs, like (19), which use no such introductory element. We will consider each type separately.

\subsubsection{Syndetic Relative Clauses}

\footnotetext{
${ }^{4}$ This conjunction is glossed as comP in Polian \& Aissen (2021).
} 
When the RC is introduced by a subordinator that is only used in the context of a RC, we treat that subordinator as a relativizer. This is a common situation in the languages of the area. An example of such a language is Ocotepec Zoque (Chiapas Zoque; Mixe-Zoquean). Evidence that the RC subordinator $=p \dot{t}^{\prime}$ in (17) is only used in RCs comes from the fact that in the syntax of complementation, the same subordinator is not used, but instead others like ke in (20a) (borrowed from Spanish que) and $w a^{\prime} a$ in (20b) are used. A subordinator that introduces complement clauses, but not RCs, is treated here as a complementizer. The same situation is found in Purepecha (isolate) in the contrast between (21a) and (21b), and in Chichimec (Pamean; Oto-Pamean), where syndetic RCs are introduced by the relativizer ndi (22a) while clausal complements in this language, as in other Oto-Pamean languages, are mostly encoded by means of asyndesis (22b). ${ }^{5}$

\section{OCOTEPEC ZOQue (MIXE-ZOQUEAN)}

(20) a. kuando diojsis 'yijsu 'un ke ji' 'yidi sa'syapi' 'ijtku'y

kuando dios='is $\quad y$-'is- $u=$ 'un

when God=ERG3 A3-see-CP=REP

[ke ji'n $\quad y^{\prime}$ 'it-i $\quad \varnothing$-sa'sa=pi' 'it-kuy']

COMP NEG.ICP S3D-exist-DEP1 S3-be.fine=REL live-NMLZ

'When they say that God saw that there isn't any life which is good.' $\{$ Txt $\}$

(Ramírez Muñoz 2016: 2)

b. rre'yis syutpa'unna'ajk wa'a syeyijtsijku kijpku'yis

rrey='is $\quad y$-sun- $p a=^{\prime} u \eta=n a^{\prime} a k$

king $=E R G 3 \quad A 3-$ want $-I C P=R E P=C O N T R$

[wa'a $y$-seyi-tsik-u kip=ku'y='is]

COMP A3-go.on-do-DEP2 fight=NMLZ=ERG3

'The king wanted the fight to go on.' $\{T x t\}$

(Ramírez Muñoz 2016: 2)

\section{PUREPECHA (ISOLATE)}

(21) a. isi ari-s-p-ka=ni ima achati-ni

so say-PFV-PST-ASSERTV[1/2]=1SG that man-OBJ

[inki $t^{\prime} u$ wanta-ni ja- $\varnothing-\varnothing-k a$ ]

REL 2SG speak-NF be-PFV-PRS-SBJV

'So I told that man that you're speaking to.' $\{$ Txt $\}$

(Chamoreau 2019: 155, 142)

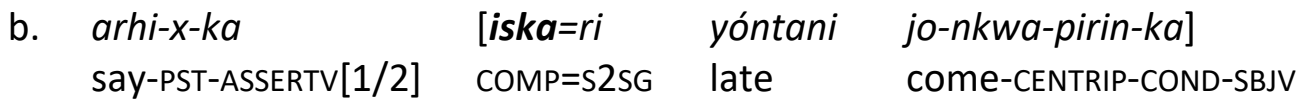

'I said that you should come back late.'

\footnotetext{
${ }^{5}$ In the orthography, $n$ and $m$ represent nasal approximants, umlaut is for a nasal vowel, and $\mathrm{H}$ is for high tone (low tone is not represented).
} 
Chichimec (Oto-PAMEAN)

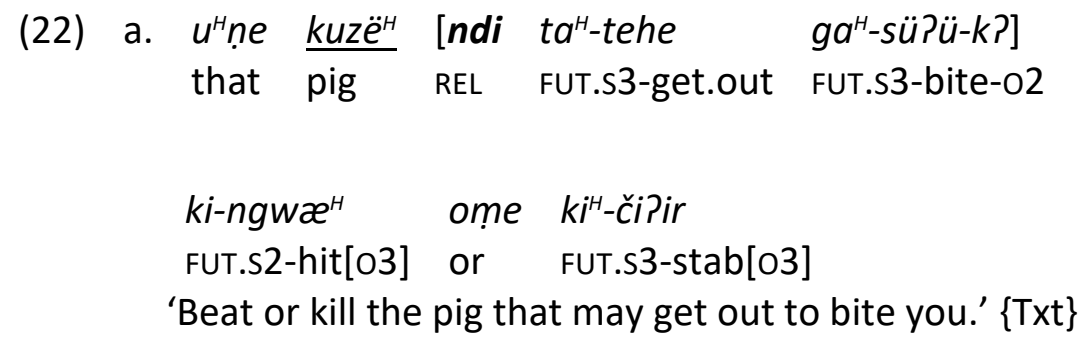

(Lastra 2018: 128, 227)

b. ikag ${ }^{H} e^{H}-n u p u \quad\left[p a h a^{H} e^{H}-n e h e\right]$

1SGPRO PRS.S1-see bad PRS.S3-get.out

'I see that it comes out bad.' $\{$ Txt $\}$

(Lastra 2018: 128, 227)

In contrast, the RC from Tseltal in (18) above illustrates a situation where a RC is introduced by a subordinator that has a wider syntactic scope. Authors commonly treat such a subordinator with the alternative label of 'complementizer', but we prefer to call it a subordinator, reserving the term complementizer for a subordinator that does not introduce RCs. The Tseltal case can be seen in (23), where the same te that introduces the RC in (18) above is also used to introduce a complement clause. Using a general subordinator is also a common strategy to introduce a RC in languages of the Mesoamerican area. It may be seen in Sochiapan Chinantec (Chinantecan) or in Ixcatec (Popolocan) in the contrasts in both (24) and (25), respectively.

TSELTAL (MAYAN)
ya $a-n a^{\prime}$
[te ya=nanix
$a-$ toj=a]
ICP A2-know[PO3] SUB ICP=EMPH+ASSERTV A2-pay[PO3]=ADV
'You know that you'll have to pay for it.' $\{$ Txt $\}$

(Polian 2013: 816)

\section{SOCHIAPAM CHINANTEC (CHINANTECAN)}

(24)
a. $k a^{L}-h e^{L M}$
$h n a^{H L} \quad\left[P^{L} \quad \eta a p^{L}\right.$
$i e^{\text {'t] }}$
PST-See.TR.INAN.1SG 1SGPRO SUB go.home.INTR.AN.PST.3SG elder
'I saw that the old man went home.'

(Foris 2000: 320)

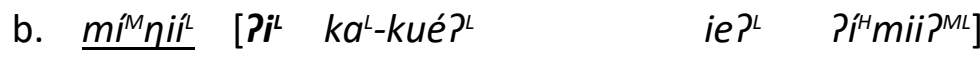
pig SUB PST-give.DTR.INAN.3SG elder bread

'The pig that the old man gave some bread to.'

(Foris 2000: 314)

IXCATEC (Popolocan)

(25) a. Pinánà tsukwa-ná [la Jwi-ri]

1SGPRo want-1SG SUB come-2HON

'I want you to come (here).' $\{T x t\}$ 
b. Suwa-ku ka trahmi [la tú-tse fàà] come-ANT all people SUB PRG.PL-do work 'All people who are working have arrived.' $\{T x t\}$

(Adamou \& Costaouec 2013: 200)

In most languages of the area, the relation between relativizers and complementizers is an intricate one. Just like English that, most such connectors have developed historically from determiners. For example, Tseltal te, which we gloss as SUB in (18) and (23), can also function as a determiner in nominal syntax (e.g. into te ermano 'this brother' or te jtatik Gabriel 'Father Gabriel'). Multifunctional elements like te are not easy to treat in a unified way for descriptive purposes, and consequently, authors commonly disagree in their analysis and their corresponding treatment in the glosses. Even the same author may suggest different treatments in different works. For example, in the spirit of using only one gloss per element, Polian (2013) glosses te in (23) as a 'determiner' (DET) rather than as a subordinator). We suggest that the functions of being a determiner, a relativizer or a fullyfledged subordinator should be kept apart in the glossing. The relation between determiner and subordinator can be subsumed in the grammaticalization path in (26), where we consider that an element's function as a relativizer precedes its change to a subordinator.

$$
\mathrm{DET} \rightarrow[\mathrm{REL} \rightarrow \mathrm{COMP}] \mathrm{SUB}
$$

In the syntax of relativization of many Mesoamerican languages, we still find the DET $\rightarrow$ REL portion of the path. When this happens, the determiner introducing the RC is (more often than not) a copy of the determiner which heads the DP in which the the domain nominal is embedded. This can be seen in languages from different phyla with no history of contact, as exemplified by the two RCS of Acazulco Otomi (Otomian; Oto-Pamean) in (27), ${ }^{6}$ or in K'ichee' (K'ichean; Mayan) in (28). Note that there are two different glossing strategies in the two sources, while the function of the elements remains the same. Hernández Green prefers to gloss the relativizer as a determiner (DET), while Velleman choses to gloss it as a complementizer (COMP).

$$
\begin{array}{lll}
\begin{array}{lll}
\text { ACAZULCO ОTOMI (ОTO-PAMEAN) } & \\
\text { pero=na } & n g u ̈\left[=n a=g \_' r a\right. & n u=a] \\
\text { but=DET.PROX.SG } & \text { house=DET.PROX.SG=S2_IPFV } & \text { see=ENCL }
\end{array}
\end{array}
$$

$k o=' r={ }^{\prime} y o t^{\prime} e$

$\mathrm{FOC}=\mathrm{POSS} 3 \mathrm{SG}=$ property

$$
\begin{array}{lll}
\boldsymbol{k}^{\prime} \boldsymbol{a}={ }^{\prime} m=\text { chi } & t^{\prime} u=g a\left[=\boldsymbol{k}^{\prime} \boldsymbol{a}=b i\right. & d \ddot{u}=a] \\
\text { DET.NVIS.SG=POSS1=DIM } & \text { SOn=1=DET.NVIS.SG=IPFV[S3] } & \text { LEN/die=ENCL }
\end{array}
$$

\footnotetext{
${ }^{6}$ Acazulco Otomi is a language with pervasive encliticization. The inflectional markers of the predicates of the two RCs in (27) (grá for IMPV.S2 and bi for PFV[s3]) encliticize to the determiners introducing the RCS, $n a$ and $k^{\prime} a$, respectively, which in turn encliticize to the last word of the DP immediately preceding the RC, which in the examples happens to be the domain nominal.
} 
'But this house you see here, it's the property of my late son.'

(Lit. '...my son who died.') $\{$ Txt $\}$

(Hernández Green 2021: 120)

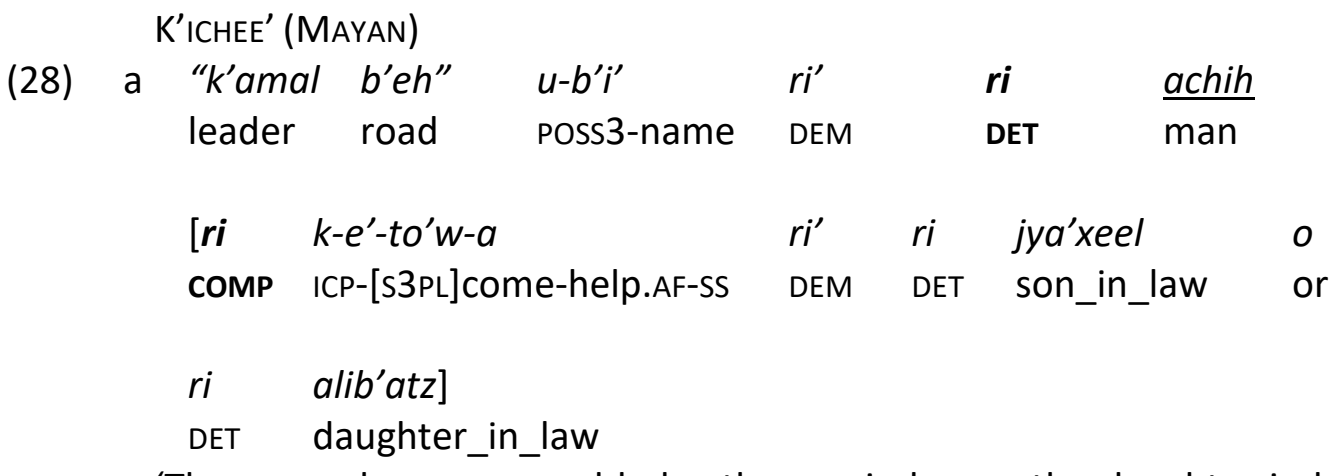

'The man who comes and helps the son-in-law or the daughter-in-law (to make a formal proposal of marriage) is called "guide".' $\{$ Txt $\}$

(Velleman 2014: 80)

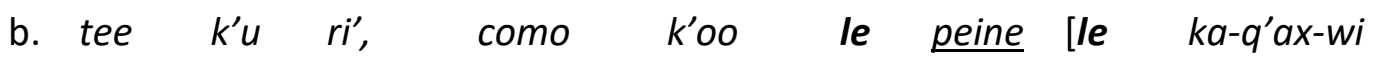

when then DEM since [s3]EXIST DET comb cOMP ICP-[s3]pass-ADJTFOC

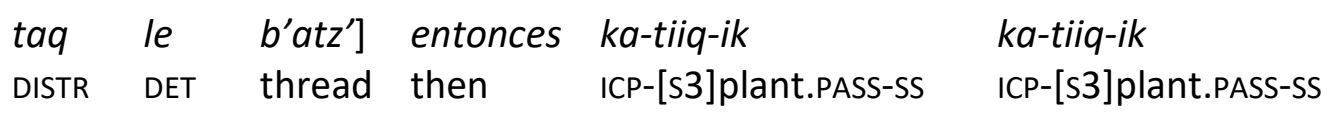

pa le xyeb'

$P \quad$ DET comb

'After that, because there is a comb that the thread passes (through), then (the thread) is set up, is set up in the comb.' $\{$ Txt $\}$

(Velleman 2014: 80)

The functional relation between determiner and subordinator stems from the link that exists between the syntax of nominalization and the syntax of subordination. Disagreement in the glossing often reflects different theoretical conceptions of the syntax behind the structures. For example, Hernández Green (2021) analyzes the headed RC construction in (27) as if it consisted of a pronoun that stands for the domain nominal; that pronoun would also serve as head of the RC. This analysis is proposed in an attempt to preserve structural coherence between the headed RCS in (27) and the light-headed RCS in (29) that function as arguments of the matrix predicate. In this spirit, the same determiner-like elements in all such RCS are all glossed as demonstratives.

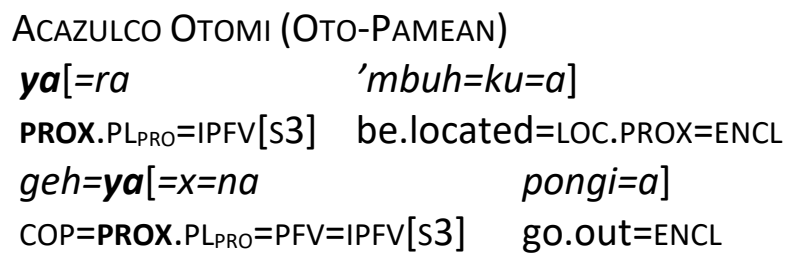

(Hernández Green 2021: 135) 
The analysis of the RCs in (29) as light-headed is based on Citko (2004), and they correspond to a well-known type in the typological literature. It is much less clear, however, what sort of headed RC type the one in the analysis proposed for (27) would be. Likewise, in the analysis of (27) it remains unclear what type of linkage relationship the RCs would have to the domain nominal (i.e., it appears to be an adjoining RC clause, when in reality it is not).

In this connection, for the same type of construction, Velleman (2016) treats the determiner in the K'ichee' RC in (28) as a 'complementizer', hence the gloss. ${ }^{7}$ We treat all such clausal linkers as relativizers. The descriptive fact that a relativizer is a copy of the determiner in the DP in which the domain nominal is embedded is accounted for in Polian \& Aissen (2021) as a case of a special type of agreement in deixis (DEIX) that targets the relativizer introducing the RC. The agreement in deixis is controlled by the head of the DP in which the domain nominal is embedded. This is shown in Tsotsil in (30), where it is claimed that the RC is introduced by the proximal determiner $l i$, if and only if the head noun occurs in a DP that is also headed by li. In contrast, subordinator ti (cognate with Tseltal te in (18) and also a determiner), which introduces the RC in (31), does not show agreement properties. Note that both linkers are glossed as 'complementizers', regardless of their functional scope. Instead, we would gloss $l i$ in (30) as a 'relativizer', and $t i$ in (31) as a 'subordinator'.

$$
\text { TSOTSIL (MAYAN) }
$$

$\begin{array}{lll}\text { bat } & k \text {-ak'-tikotik } \quad \text { il-uk } \\ \text { go } & \text { A1-give-1PL.EXCL } & \text { see-SBJV }\end{array}$

$$
\begin{array}{lllllll}
\text { li } & \text { j-vun-tikotik } & \text { li } & \text { kok'-em } & \text { ta } & \text { Tuxta } & \text { un=e }] \\
\text { DET } & \text { POSS1-paper-1PL.EXCL } & \text { COMP } \text { DEIX }^{\prime} & \text { leave-PFV } & \text { P } & \text { T. } & \text { PRTCL=CL }
\end{array}
$$

'We went to show our papers that had been issued in Tuxtla.' $\{T x t\}$

(Polian \& Aissen 2021: 411)

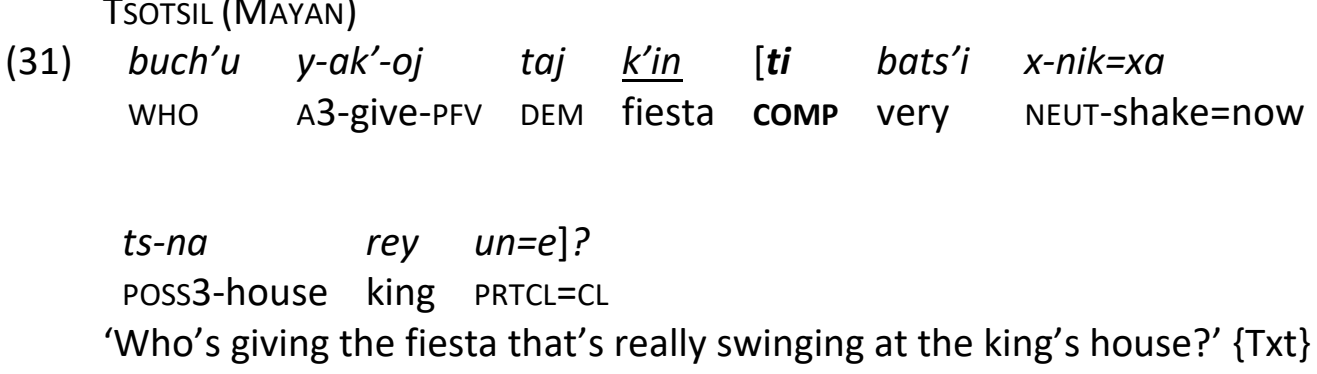

(Polian \& Aissen 2021: 411)

Note that the element $l i$ in the RC in (30) is not analyzed as a relative pronoun, because deixis is not conceived of as being a feature of the head noun, but as a property of the DP in which the head noun is embedded. A relativizer that serves as a target of agreement in deixis is typologically uncommon, but as the construction is widespread in Mesoamerican languages, it should be seen as particular to this linguistic area. It is found from languages that lie geographically at the core of the area to languages that are spoken at its fringes, such as Cora, in (32), where Vázquez Soto (2002: 330) glosses the element $f$ introducing the

\footnotetext{
${ }^{7}$ The term 'complementizer' is used by Velleman (2016) in a generic way equivalent to subordinating linker without having in mind any specific context of subordination.
} 
RC as a determiner (just as Hernández-Green (2021) does for (27), and Polian (2013) does for (18)). Instead, we analyze it as a relativizer that agrees in deixis. This type of RC alternates with asyndetic RCS (see next section).

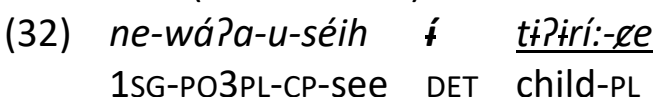

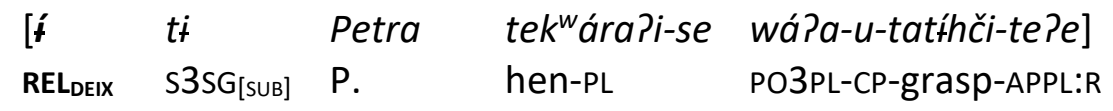

'I saw them, the children who Petra gave some hens to.'

(Vázquez Soto 2002: 330)

In our view of things, concepts such as 'relativizer', 'complementizer' and 'subordinator' are not just terminological trifles, but powerful descriptive categories that are informative about the syntactic functional scope of subordinating linkers. Furthermore, the syntactic properties behind the relative constructions in (27), (28), (30) and (32) can only be explained in morphosyntactic terms if the category of a 'relativizer' is taken to be a distinct entity from a 'complementizer' or a 'subordinator'. The linker $t i$ in Tseltal in example (31) stops showing agreement properties the moment it stops being a relativizer like li still is in (30). Only relativizers can be the target of agreement with the head of the DP in which the domain nominal is embedded, while a subordinator may show agreement in feature values associated with the clause, such as TAM, although more typically person/number of the subject (see Fuß 2005).

\subsubsection{Asyndetic Relative Clauses}

In the previous section, we have seen cases where the RC is introduced by a linking element. It is equally common to find RCS with a gap that have no linking word introducing them. We treat such cases as instances of asyndetic RCs. In the literature, analyses inspired by generative models of syntax often treat such RCs as bearing a zero complementizer, that is, a subordinator that happens to have no phonological expression, but which is, nonetheless, interpreted as being present in the syntax in order to make sense of the arboreal structure proposed in such models. An example of an asyndetic RC was already shown in Tilapa Otomi in (19). Asyndetic RCS are widespread in Mesoamerica, as they are found in genetically unrelated languages, such as: Mayan, as shown in Tseltal in (33) (comparable with (18) above) or in Q'anjob'al (Q'anjob'alan; Mayan) in (34); Tlaxcala Nahuatl (Nahuan; UtoAztecan) in (35); or Zenzontepec Chatino (Chatino; Zapotecan) in (36).

TSELTAL (MAYAN)

\begin{tabular}{|c|c|c|c|c|c|c|}
\hline$|a=b a|$ & $a w-i l$ & $\underline{t e}$ & mensaje & {$[/ a$} & j-tikun-b-at & bel]=e? \\
\hline CP.TR=INTER & A2-see[PO3] & DET & message & CP.TR & A1-send-APPL:R-PO2 & $\mathrm{DIR}+\mathrm{NF}=\mathrm{DE}$ \\
\hline
\end{tabular}

(Polian 2013: 784)

Q'ANJOB'AL (MAYAN)

(34)

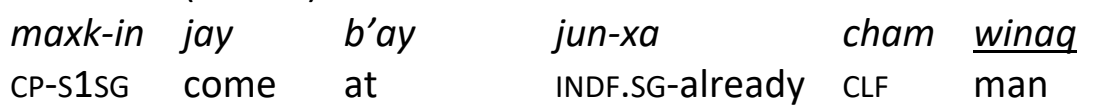




$$
\begin{aligned}
& \text { [max- } \varnothing \quad q^{\prime} a \text {-toq } y \text {-aqan] } \\
& \text { CP-S3 rot-DIR POSs3-foot } \\
& \text { 'I came to another man whose feet were rotten.' }\{T x t\}
\end{aligned}
$$

(Mateo Toledo this volume)

Tlaxcala Nahuatl (Uto Aztecan)

(35)

$\begin{array}{llllll}\varnothing \text {-katka } & \text { se } & \text { tlaka-tsintli } & {[\varnothing \text {-i-toka }} & \text { "Juan } & \text { Loco"] } \\ \text { s3-exist.IPFV } & \text { INDF } & \text { man-HON } & \text { s3-POSs3sG-name.IPFV J } & \text { crazy }\end{array}$

'There was a man named Crazy John.' $\{$ Txt $\}$

(Flores Nájera this volume)

ZeNZONTEPEC ChATINo (ZAPOTECAN)

(36) nk-ā+tāká tzaka nyatēe [?ne jnyá]

PFV-BE+exist one person HAB.do[3] work

'There was a person that worked.' $\{$ Txt $\}$

(Campbell this volume)

When asyndetic RCS are found in a language, they often coexist with other types of RCS that use a gap strategy but exhibit a linker. Compare example (33) with (18) in Tseltal, or example (35) with (37) in Tlaxcala Nahuatl, and (36) with (38) in Zenzontepec Chatino, where both languages use a subordinator.

TLAXCala Nahuatl (Uto Aztecan)

\begin{tabular}{|c|c|c|c|c|}
\hline \multirow{3}{*}{ (38) } & \multicolumn{4}{|c|}{ ZENZONTEPEC CHATINO (ZAPOTECAN) } \\
\hline & $n k w-i s \bar{u}=\bar{u} ? \quad j-n \bar{a}$ & kwetā.kya?ā? & {$[n u$} & $n k-y a q]$ \\
\hline & PFV-pay=3PL $\quad$ DAT-DEF & Mixtec & SUB & PFV-come.back[3] \\
\hline
\end{tabular}

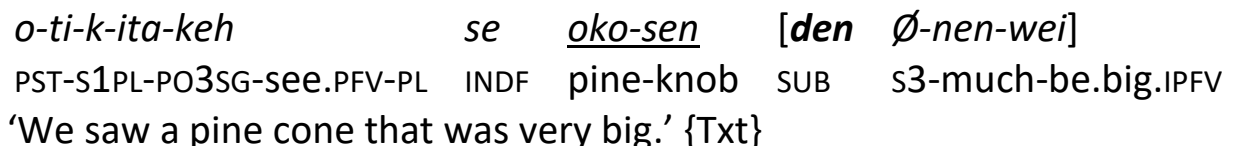

(Flores Nájera this volume)

(Campbell this volume)

In this connection, the asyndetic RC construction in Cora in (16) above, repeated here as (39), is particularly interesting, because the RC is not introduced by a dedicated lexical subordinator, so in this sense it is asyndetic, but it exhibits a set of subject pronominals that are only used in a subordinated clause. Compare the third person singular pronominal clitics $p u$ and $t i$ in (39). The first is only used in matrix clauses, whereas the second is used only in subordinated clauses (Vázquez Soto 2002: 296). ${ }^{8}$

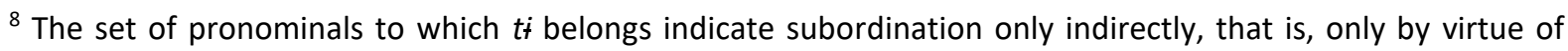
their distribution in subordinated clauses. In this sense, the subordinating clitics indicate subordination just as subjunctive mood often does too. The sets of pronominal enclitics (with subordinating clitics given second) are 1SG nu vs. neh; $2 \mathrm{sG}$ pe vs. peh; 3SG pu vs. ti; 1PL tu vs. teh; 2PL su vs. seh; and 3PL mu vs. meh (Vázquez Soto 2002:284). The phonological composition of the subordinating set suggests that the element /eh/is a historical residue of an old subordinator that received agreement for subject. But the fact that there is suppletion for
} 
CORA (UTO-AZTECAN)

(39)

\begin{tabular}{|c|c|c|c|}
\hline kú:kuPu & pu & wa-mípi $\quad[t \dot{t}$ & $\left.m^{w} a-c ̌ e ́ i h\right]$ \\
\hline viper & S3SG & CP-die.sG S3SG[sub] & O2sG-bite.PST \\
\hline
\end{tabular}

When both syndesis and asyndesis are available in a given language as two encoding options for a RC, the choice of one construction over the other appears to be free for most cases, but there are situations where the choice is restricted. ${ }^{9}$ For example, for Zenzontepec Chatino, Campbell (this volume) argues that the distribution is conditioned by information structure, in such a way that when the head noun is specific and topical, the asyndetic encoding is preferred. At times one can see that there are collocation restrictions. In Tilapa Otomi (Otomian; Oto-Pamean), for the relativization of instruments RCs introduced by a relativizer are preferred over asyndetic RCs, while the latter are the only available means to relativize the subject of property concepts (see Palancar this volume). In other languages like Chichimec (Pamean; Oto-Pamean), a V-final language, postverbal RCS (40) are asyndetic by default. This happens when the RC is extraposed (40a), or when it is integrated within the phrase of a domain nominal that also occurs postverbally (40b). In contrast, RCs preceding

person in the third person singular and that the clitics do not need to appear at the left edge of the subordinated clause (a typical position for subordinators) (Vázquez Soto 2002: 299) strongly suggests that synchronically they constitute a lexicalized set of bona fide pronominals.

${ }^{9}$ One of such languages is Santa María Piñoles Mixtec (Mixtecan). In this language, asyndetic RCs are used irrespectively of the animacy of the domain nominal: in (i.a), the head is human; in (i.b) it is inanimate. In contrast, syndetic RCs introduced by a subordinator are only restricted to inanimate heads. This is shown in the contrast in (ii). Example (iii) further shows that the subordinator is used to introduce complement clauses. The animacy restriction of syndetic RCs is lifted when the RC is used as a headless RC in a cleft, like in (iv).

i. $\quad$ a. $n i^{3}-x i^{2} n i^{2}=i^{3} \quad \frac{i^{3} n a^{2}}{d o g} \quad\left[n i^{2}-x i^{2} i^{3}\right]$

CP-see $=$ S1SG $\quad \overline{\text { dog }} \quad$ CP-die

'I saw the dog that died.' (Ramírez Pérez 2014: 63)

b. $n i^{2}-t n a^{1} n u^{2} \quad \underline{m a^{1} c h i^{2} t i^{3}} \quad\left[n i^{2}-x e^{2} n d e^{2} \quad n d i^{\prime} \dot{t}^{23}=n \quad y u^{2} t n u^{23}\right]$ CP-break machete CP-cut with=s2SG tree

'The machete with which you cut the tree broke.' (Ramírez Pérez 2014: 67)

ii. a. $n i^{3}-x i^{2} n i^{2}=i^{3} \quad \underline{m a^{1} c h i^{2} t i^{3}} \quad\left[\begin{array}{lll}s a a^{12} & n i^{2}-t n a^{1} n u^{2}\end{array}\right]$

CP-see $=$ S1SG machete SUB CP-break

'I saw the machete that broke.' (Ramírez Pérez 2014: 62)

b. $\left.\quad * n i^{3}-x i^{2} n i^{2}=i^{3} \quad \frac{i^{3} n a^{2}}{d s a a^{12}} n i^{2}-x i^{2} i^{3}\right]$

CP-see=S1SG dog SUB CP-die

Intended reading: idem (i.a) (Ramírez Pérez 2014: 63)

iii. $\quad x i^{2} n i^{3}=O^{2} \quad\left[\operatorname{sad}^{12} \quad n d a u^{12}=o^{21}\right]$

[ICP]see=s1PL.INCL SUB be.poor=s1PL.INCL

'We know that we are poor.' \{Txt\} (Ramírez Pérez 2014: 63)

iv. $\quad \tilde{n} a^{1} d \dot{t}^{\prime} \dot{t}^{23} \quad k u u^{23} \quad\left[\begin{array}{lll}s a a^{12} & n i^{3}-k a^{1} b a^{12}\end{array}\right]$

woman [ICP]COP2 SUB CP-fall

'The woman is the one who fell.' (Ramírez Pérez 2014: 179) 
the matrix verb, which are always integrated, are syndetic by default. This happens when the phrase of the domain nominal is a constituent in the matrix clause (41a), or when it is a topicalized independent constituent (41b). The right edge of the verbal phrase is indicated by $/ /$.

Chichimec (Oto-PAMEAN)

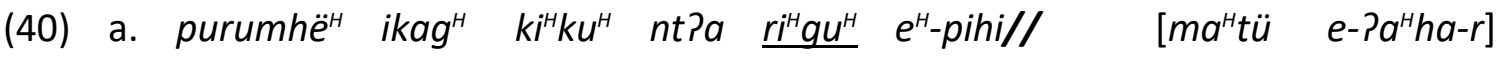
but 1SGPRO here one stick PRS.S1-bring dead PRS.s3-speak-PL[03] 'But I'm carrying a stick that makes the dead speak.' $\{$ Txt $\}$ (Lastra 2018: 126)

b. $e^{H} n t ? a$ ki ru-nhu ${ }^{H} / / \quad e^{H} n t ? a \quad u^{H} r^{H} \quad\left[t^{H}\right.$ ahyr ${ }^{H} e^{H}-p i h i$ one and SEQ.S3-see.S3PL one person rifle PRS.S3-bring

$\left.e^{H}-m æ h æ \quad i^{H}-k h a r\right]$

PRS.S3-be IMM.PST.S3-have

'And then they found one man who's carrying a rifle and is getting ready.' $\{$ Txt $\}$

(Lastra 2018: 190)

CHICHIMEC (OTO-PAMEAN)

(41)

$\begin{array}{lllllll}\text { a. } i k a g^{H} & k i i^{H} & k a^{H} n d a n P^{H} & \text { [ndi } & \left.k a^{H} \text {-tehe }\right] & k e P e n^{H} & g a^{H}-n d y P^{2}-r \\ 15 G_{\text {PRO }} & \text { these } & \text { worker } & \text { REL } & \text { PRS.S1-come } & \text { also } & \text { FUT.S3-go-PL[s3] }\end{array}$

$\begin{array}{lll}\text { u }^{H} \text { rhan? } & g a^{H} \text {-rhan?// } & \text { Pi } \\ \text { POSS3PL.work } & \text { FUT.S3-work.S3PL } & \text { PRTCL }\end{array}$

'As for me, these workers I'm bringing will also go and do their work!' \{Txt $\}$

(Lastra 2018: 123)

b. ba $n a i^{H}$ čičaha? [ndi u-nda'ha-b],

all bird REL PST.S3-ask-DAT3

$\begin{array}{llll}u^{H}-m h \ddot{a} / /: & \text { "ni } & p a^{H} m e^{\prime \prime} ; & m a n i^{H} \\ \text { PST.S3-say.S3PL } & \text { nor } & \text { no } & \text { something }\end{array}$

su-nhu $u^{H}-m e$

NEG.S3-see.S3PL-NEG

'All birds he asked, all birds said: "not at all"; they know nothing.' $\{$ Txt $\}$

(Lastra 2018: 192)

\subsubsection{The Relative Pronoun Strategy}

RCS may also be introduced by a relative pronoun, and although this strategy is far less common in Mesoamerican languages, ${ }^{10}$ we still find it in all languages of the area when the

\footnotetext{
${ }^{10}$ See Comrie (2003) and Comrie and Kuteva (2005) who argue that, not only is the relative pronoun strategy common just in the languages of Europe, but perhaps it is only characteristically developed in the languages of Europe.
} 
domain nominal has the semantic role of a location in the RC. This is shown in Zenzontepec Chatino (Chatino; Zapotecan) in (42) and in Chol (Cholan; Mayan) in (43).

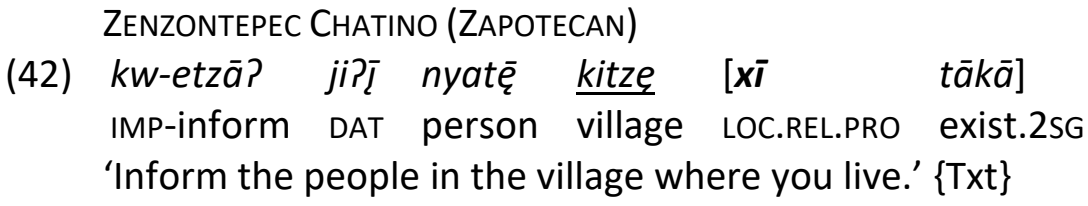

(Campbell this volume)

CHOL (MAYAN)

(Martínez Cruz 2007: 177)

Given the fact that the locative relative pronoun strategy is so widespread in the area, we take it to be a typical trait of the RC structure of a Mesoamerican language, but it is not unique to the area, because it is also found in Chibchan languages like Pesh (see Chamoreau this volume). Beyond the locative, languages of the area differ greatly as to the scope of this strategy and the size of the set of relative pronouns available in headed RCS. For example, in Tilapa Otomi (Otomian; Oto-Pamean), the relative pronoun strategy is only used for the relativization of a human subject (or a human possessor), as shown in the contrast in (44). Exactly the same situation is found in Zenzontepec Chatino (Chatino; Zapotecan). Example (45) shows the relativization of a possessor. In other languages, like Tseltal and Tsotsil (Mayan), the important thing is that the referent of the domain nominal is human, regardless of whether it plays the role of subject or object in the RC (Polian \& Aissen 2021). But there are also languages like Texistepec Zoque (Gulf Zoquean; Mixe-Zoquean), as shown in Díez Alejandre (2019), where relative pronouns are found for any role in the hierarchy, except subject. This suggests that (disregarding relativization of locative and genitive) the relative pronoun strategy may develop in two opposite ways: starting at the top of the relativization hierarchy down (stopping at human subject or human object); or starting bottom up, but stopping at object so that the construction does not end up being a basic relativization strategy.

$$
\begin{aligned}
& \text { TILAPA OTOMI (OTO-PAMEAN) }
\end{aligned}
$$

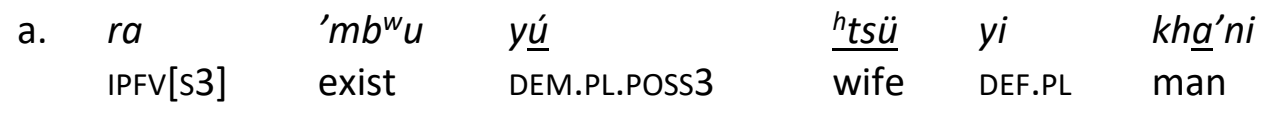

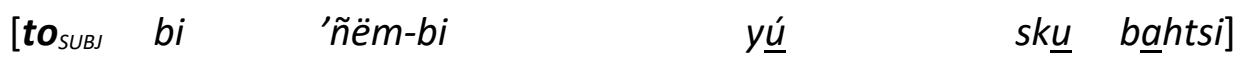

$$
\begin{aligned}
& \text { WHO PFV[S3] SS/bear.child.AS-DAT3 DEM.PL.POSS3 DIM child } \\
& \text { 'The men have wives who gave them children.' } \\
& \text { (Lit. 'The men's wives exist who...') }\{\text { Txt }\} \quad \text { (Palancar this volume) }
\end{aligned}
$$

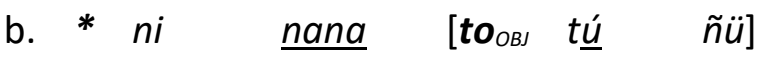

$$
\begin{aligned}
& \text { DEM.SG woman WHO PFV.S1 see } \\
& \text { Intended reading: 'The woman that I saw.' }
\end{aligned}
$$




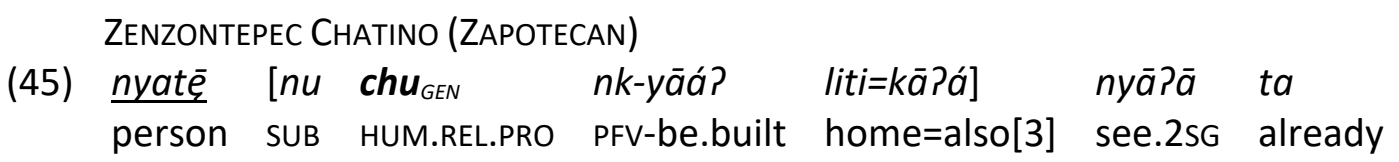

nkwātí?=ū? tula ?ne=ū?

PFV.knOW $=3 \mathrm{PL}$ WHAT POT.do=3PL

'The people whose homes were also built, you see, they already knew what they were going to do.' $\{$ Txt $\}$

(Campbell this volume)

Relative pronouns are often recruited from the paradigm of WH-words, as is the case for the relative pronouns of Mayan languages like Chol in (43) (also in Q'anjob'al, Mateo Toledo this volume) and in Tilapa Otomi in (44). But in many other cases, they are not WH-words, like in Zenzontenpec Chatino in (42) or (45). In this connection, a likely alternative origin for relative pronouns is nominal classifiers. This is particularly evident in some Mixtecan languages, such as Nieves or Melchor Ocampo Mixtec, as shown in (46) and (47). In these examples, we can see that the domain nominal depicts an animal and carries a noun classifier for animals; the same element is used as a relative pronoun (for subject).

$$
\text { NieVES Mixtec (MixteCAN) }
$$
a. kïrī
tyīna sāsī=rī
CLF.ANIM dog ICP.eat=AN chocolate
'The dog eats chocolate.'

(Caponigro et al. 2013: 64)

b. Jwán kúni=ra

tyīna $[k \bar{r} r \bar{i}$

J. ICP.want=3SG.M dog ANIM.REL.PRO

sāsī jípva]

'Juan wants the dog that eats chocolate.'

ICP.eat chocolate

(Caponigro et al. 2013: 64)

Melchor Ocampo Mixtec (MixteCAn)

(47)
a. $\boldsymbol{t}^{\mathrm{i}}$
ก̃u?ก̃u
tùvi=ri
yù?u
CLF.ANIM bee
CP.sting $=\mathrm{AN} \quad 1 \mathrm{SG}_{\mathrm{PRO}}$

'The bee stung me.'

(Caponigro et al. 2013: appendix 4)

b. sàte=i burro $[t \bar{t} \quad$ yaxi chòkòlatè $]$

CP.buy=1SG donkey ANIM.REL.PRO ICP.eat chocolate

'I bought the donkey that eats chocolate.'

(Caponigro et al. 2013: appendix 4)

Note that the situation in (46) and (47) is different from the one depicted above in examples like (30), which involved a relativizer that agrees in deixis. Here the choice of the relative pronoun relies on the class of the noun, independent of whether or not the domain nominal is itself marked with that nominal classifier (i.e., in (46b) and (47b), the domain nominal is unmarked when it is in focus). Once the classifier establishes itself as a relative pronoun, it is 
free to have an independent life as a lexical item and it may lose its function as a classifier. In this sense, the relative pronouns in some languages may still display certain uses as classifiers that remind us of their diachronic origins. Such is the case in Zenzontepec Chatino, as illustrated in (48), where the relative pronoun for humans chu shown in (45) above, still survives in nominal syntax as a classifier for humans when used with adjectives to produce nominalizations. Note that the RC in (48) is a headless RC in apposition to the phrase 'the poor'. ${ }^{11}$

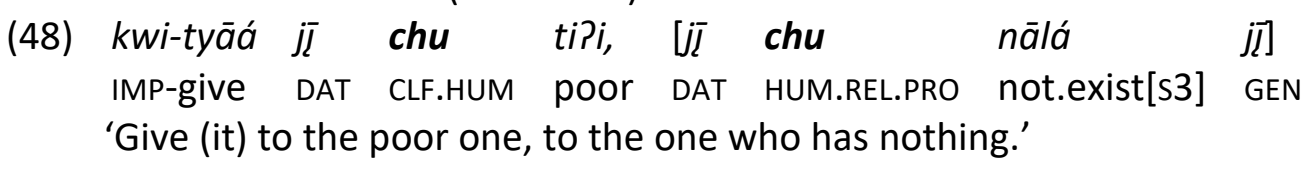

(Campbell this volume)

\subsubsection{Internally-Headed Relative Clauses}

The maximal expression of the domain nominal in a RC is by way of the nominal itself, resulting in internally-headed RCs. Zoquean languages that preserve the old OV word-order display this type of RC, as illustrated by Ocotepec Zoque (49) and San Miguel Chimalapa Zoque (50). In both (49) and (50), the domain nominal functions as the intransitive subject of the matrix clause, but it is flagged by ergative or comitative case, respectively, according to its role in the RC.

(49) te' ki'subitsi tuwi'is ka'u

$$
\begin{array}{llll}
t e^{\prime} & {\left[\varnothing-k \dot{t}^{\prime} s-u=p \dot{t}^{\prime}={ }^{\prime} t s i\right.} & \text { tuwi'='is }] & \emptyset-k a^{\prime}-u \\
\text { DET } & \text { PO1-bite-CP=REL=1ABS } & \text { dog=ERG[3] } & \text { s3-die-CP }
\end{array}
$$

'The dog that bit me died.'

(de la Cruz Morales 2016: 114)

San Miguel Chimalapa Zoque (Oaxaca Zoque)

(50) mari pinjinang witti' mi'tyyí

[mari pin=jinang $\left.\varnothing=w i t-w \dot{t}=p \dot{t}^{\prime}\right] \quad \varnothing=m \dot{t}^{\prime} \dot{t} y-w \dot{t}$

M. $\quad$ man=COM s3.I=walk-CP.I=REL s3.I=get. married-CP.I

'The man with whom María was involved got married.'

(Jiménez 2014: 318)

Whereas having internally-headed RCs is a structural possibility linked to the language being V-final, not all V-final languages have internally-headed RCs. Chichimec, a language spoken at the fringes of Mesoamerica, is particularly revealing in this respect. Chichimec is the only Oto-Pamean language that is V-final, however, it has no internally-headed RCS, but has preserved instead the typical configuration of a $\mathrm{V}$-initial language with the relativizer to the left of the RC. This is illustrated in (51). Note that the clausal predicate occurs at the rightedge both in the RC and in the matrix clause.

\footnotetext{
11 In Matlatzinca, the general singular classifier $n$, which at some point in its diachrony may have worked as a relative pronoun, has now been reanalyzed as a relativizer, because it is no longer sensitive to the number feature value of the domain nominal (see Palancar \& Carranza 2021).
} 


CHICHIMEC (OTO-PAMEAN)
$\begin{aligned} & \text { (51) } \\ & \text { úri } \quad \text { [ndi múra é-tó-r] }\end{aligned}$ ubebé é-sé...
'He then said to the person who takes care of the donkeys...' $\{$ Txt $\}$

(Lastra 2018: 394)

A language may exhibit RCs that on the surface appear to be internally-headed, when in reality a better alternative analysis can be posited for them. This is particularly the case for Nahuan languages, as illustrated by Tlaxcala Nahuatl in (52).

TLaXcala Nahuatl (Uto-Aztecan)

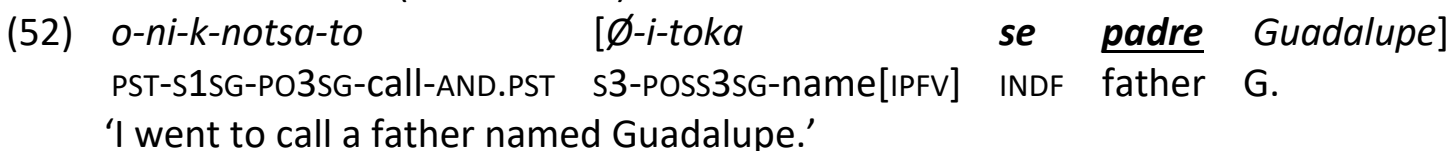

(Flores Nájera this volume)

Flores Nájera (this volume; 2021) argues convincingly that the RC in (52) is not an instance of an internally headed RC. Instead, the occurrence of the phrase encoding the head inside the $\mathrm{RC}$ is explained as an effect of the lack of syntactic configurationality in Nahuatl (see Flores Nájera 2019 for an extensive discussion). Flores Nájera argues that RC structure is particularly the target of syntactic scrambling, giving rise not only to surface realizations like (52), but also to others like (53), where the DP in which the domain nominal is embedded may appear inside a RC that already exhibits a relative pronoun standing for the domain nominal.

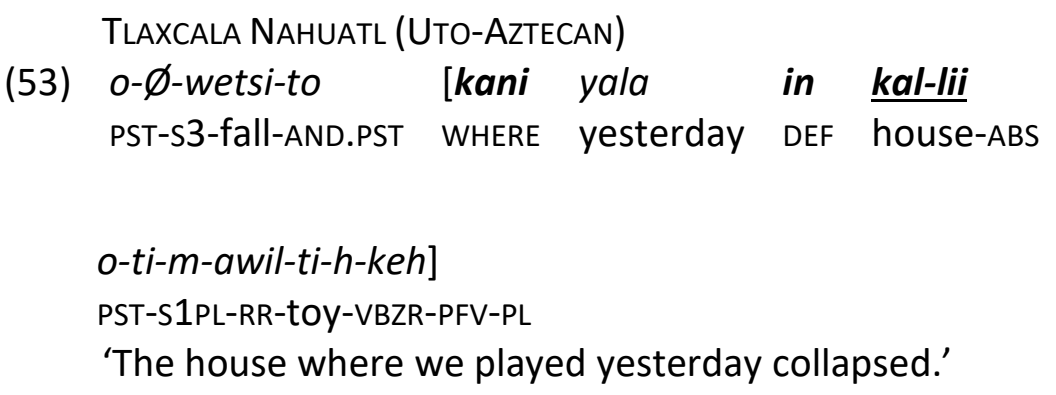

(Flores Nájera this volume)

Flores Nájera (this volume) argues that non-configurationality is the only analysis that can encompass examples like (52) and (53) in a theoretically sound manner. She further claims that such an analysis should be extended to other Nahuan languages, where similar phenomena have been reported in the literature, such as for Morelos Nahuatl as illustrated in (54). This example has two RCs, one embedded within the other. Our interest is in the first $\mathrm{RC}$, where the domain nominal kwawitl 'tree' appears within the RC after the subordinator tlin, and is split from its quantifier nochi 'every'. The second RC is a prenominal RC encoding a property concept.

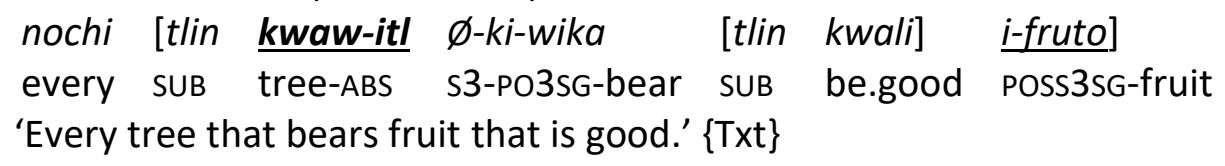

Morelos Nahuatl (Uto-Aztecan) 
Similar phenomena to the one observed in Nahuatl have been reported in Totonac. In Upper Necaxa Totonac (Totonacan; Totonac-Tepehuan), Beck (2016) discusses instances of RCs that have the domain nominal inside the RC, as shown in (55a). The relative construction in (55a) contrasts with the more canonical one in (55b), which involves an externally-headed postnominal RC.

\section{UpPer NeCAXa Totonac (Totonac-TePehuAn)}
a. [ti: ta-li:-ta-tse?-a
Pawačá-n
išs-tsi:-kan]
WHO S3PL-INSTR-DECAUS-hide-IPFV boy-PL POSS3-mother-PL.PO
'Those boys that hide behind their mothers(' skirts)' $\{\mathrm{Txt}\}$

(Beck 2016: 40)
b. Pawačá-n [ti: ta-li:-ta-tse?-a iš-tsi:-kan] boy-PL WHO S3PL-INSTR-DECAUS-hide-IPFV POSS3-mother-PL.PO 'Those boys that hide behind their mothers(' skirts)'

(Beck 2016: 40)

Note that the structure of an example like (55a) is the same as the Nahuatl example in (53). In the absence of an analysis based on non-configurational syntax, Beck (2016) is forced to propose that the element ti: introducing the RC in (55a), which we gloss as 'WHO', is not a relative pronoun, but a relativizer that happens to agree with the head noun in animacy. We believe that such a solution should be avoided to prevent the risk that the descriptive category of relative pronoun becomes theoretically vacuous. We propose, instead, that a hypothesis of (non-)configurational syntax should be first tested in analyzing the word-order syntax of Totonac at large, in order to see if it is possible to keep the syntax of RCs in Totonac coherent with the received typology on RCs.

Beyond the southern borders of the Mesoamerican area, $\mathrm{V}$-final languages also display proper internally-headed RCS. This is seen for example in Pesh (Chibchan), where the construction is only restricted to the relativization of core arguments. For non-core arguments, a gap strategy is used. Compare (56a) with (4) above, repeated here as (56b).

$$
\text { PESH (CHIBCHAN) }
$$

(56) a. tàsmà kàpàn kàpàn kórtà tayè? kàtfềmirà wífkarí

$\begin{array}{llll}\text { tas }=m a & {[k a p a n-k a p a n} & \text { korta } & \text { ta-ye? } \\ 1 \mathrm{SG}_{\mathrm{PRO} O}=\mathrm{TOP} & \text { morning-morning } & \text { woman } & \text { POSS1-small }\end{array}$

$$
\begin{array}{ll}
\varnothing \text {-ka-tfã- } \varnothing \text {-pi]=ra } & \varnothing \text {-wif-k-a-ri } \\
\text { O3sG-APPL:R-see-s3sG-FUT=ABS } & \text { 03sG-give.03-?-s1sG-PST }
\end{array}
$$

'I entrusted him to the woman who will take care of my son every morning.' $\{$ Txt $\}$

(Chamoreau this volume)

b. kúkàrskà yèrhá tàkiíyó úhàrí

$$
\begin{aligned}
& \text { kukarska [ye?-ha ta-ka- } \varnothing \text {-i]=yo } \\
& \text { hoe small-NMLZ 01-hit-S3SG-PST=INSTR O3sG-hide-S1SG-PST } \\
& \text { 'I hid the hoe with which the small boy hit me.' }
\end{aligned}
$$




\subsection{The Relativization Hierarchy}

\subsubsection{Relativizing Core Arguments}

In most Mesoamerican languages, the basic relativization strategy revolves around the S/A pivot, treating the subject of intransitive and transitive verbs alike for relativization purposes. But in many Mayan languages, such as Yucatec, Tsotsil, and those of the Q'anjob'alan, Mamean and K'ichean branches (Dayley 1981, 1990; Stiebels 2006) there is a special treatment of the A relation in relativization. The grammatical construction used to relativize an $A$ is known in the literature as 'agent focus'. The name is used because the construction is also used when the A relation is in focus or is the target of interrogatives. The fact that a similar construction is used to treat the A relation in RCs, focus and interrogation can be taken as indicative of the fact that all three constructions are treated by speakers as different instances of the syntactic extraction of an A. Examples of the agent focus construction in Q'anjob'al in the three syntactic contexts are given in (57). Note that no special voice changing mechanism is needed for the relativization of $\mathrm{S}$ or $\mathrm{O}$, as shown in (58); the same is true for focus and interrogation (see Mateo Toledo (this volume) for more details, or Zavala Maldonado (2017a) for constructional idiosyncrasies in the family).

Q'ANJOB'AL (MAYAN)

$$
\begin{aligned}
& \text { a. komo ay- } \varnothing \quad \leq s>-c h^{\prime} e n \text { heb' naq [ch- } \varnothing \text {-kol-on-i] } \\
& \text { since EXIST-S3 POSS3-gun PL CLF ICP-S3-help-AF-FS } \\
& \text { 'Because they have guns that help them.' }\{\text { Txt }\}
\end{aligned}
$$

(Mateo Toledo this volume)

b. heb' naq winaq ti q-in kol-on b'el PL CLF man DEM POT-S1SG help-AF moment 'These men are the ones who will help me for now.' $\{T x t\}$

(Mateo Toledo this volume)

$\begin{array}{lllll}\text { c. maktxel } & c h^{\prime}-\varnothing \text {-ih-on-kan aj jun } & \text { nuq'ej ti? } \\ \text { WHO ICP-S3-take-AF-DIR DIR INDF.SG } & \text { voice } & \text { DEM } \\ \text { 'Who is saving this voice?' }\{\text { Txt }\} & & & \end{array}$

(Mateo Toledo this volume)

Q'ANJOB'AL (MAYAN)

(58) ay- $\varnothing$ juntzan heb' naq winaq [ch'- $\varnothing$-ek' kayti] EXIST-S3 INDF.PL PL CLF man ICP-S3-pass here 'There are some men who pass here.' $\{$ Txt $\}$

(Mateo Toledo this volume)

In the general situation, languages draw distinctions between the relativization of core arguments and the relativization of other roles. In Zoochina Zapotec (Zapotec; Zapotecan), for example, recipients, comitatives and instrumentals, which are commonly introduced in a clause as oblique arguments, are relativized by being promoted to $O$ status through verbal 
applicatives. This is shown in the contrast between (59) and (60). The phenomenon is so consistent across the languages of the area that a study of relativization is not only useful but required to fully understand the syntax of applicatives.

$$
\text { ZOOCHINA ZAPOTEC (ZAPOTECAN) }
$$

(59) a. shghànàbò?nh Iháó bénéká?

$$
\begin{aligned}
& \text { sh-yêgh-nà } b=o^{\text {’ }=n h} \text { Ihàò béné'=ká' } \\
& \text { IRR-go-ask.for=NOM2sG=3INAN.O to person=PL.DIST } \\
& \text { 'You're going to ask those people for it.' }
\end{aligned}
$$

(López Nicolás this volume)

b. yîdó Ihénh nâdà?

$$
\begin{aligned}
& \text { y-ídé=ò? Ihénh nhàdà } \\
& \text { IRR-come=NOM2SG with 1SG } \\
& \text { 'You'll come with me.' }\{\text { Txt }\}
\end{aligned}
$$

(López Nicolás this volume)

$$
\text { ZOOCHINA ZAPOTEC (ZAPOTECAN) }
$$

(60) a. ...bénénh'nhónh' bshàbdò' gó'nè?

$$
\begin{aligned}
& \underline{b e ́ n e ́}^{?}=n h \grave{a}^{?} \quad\left[n h o ́+n h \grave{a}^{?} \quad b \text {-shàb=d=ò? gó? } n=n h \grave{a}^{?}\right] \\
& \text { person=DEF WHO CP-offer }=\text { GEN.APPL }=\text { NOM2SG bull=DEF } \\
& \text { '...the person to whom you offered the bulls.' }\{\text { Txt }\}
\end{aligned}
$$

(López Nicolás this volume)

b. ...bwixé nhó'ólhénh? zézálhénhà?

$$
\begin{aligned}
& \text { b-bíxé nhó ólhé=nhà? [z-ey+zà'-lhénh=á'] } \\
& \text { CP-fall woman=DEF PFV-come.to.origin-COM.APPL=NOM1SG } \\
& \text { '...The woman with whom I came fell down.' }
\end{aligned}
$$

(López Nicolás this volume)

\subsubsection{Adpositional Stranding vs. Pied-Piping}

When languages do not make use of the applicative strategy to relativize non-core roles, they commonly use adpositional stranding, as illustrated in the contrast between (61a) and (61b) in Jamiltepec Mixtec.

\section{JAMILTEPEC MIXTEC (MIXTECAN)}

(61) a. kwahan ra chihín yañi ra

CP.go he with brother.of.male he

'He's going with his brother.'

(Johnson 1988: 25)

b. lialui [cha viichi ra chihín _ ]

woman SUB CP.come he with

'The woman that he's coming with.'

(Johnson 1988: 70) 
In a language that uses the gap strategy, it may be the case that adpositional stranding is not found. As a consequence of this, roles that are otherwise encoded obliquely in matrix clauses are not encoded at all in RCs, like in Zenzontepec Chatino, as seen in the contrast between (62a) and (62b).

ZENZONTEPEC CHATINO (ZAPOTECAN)
a. tāká=ya wi? ló?ō juti=ā?
exist=1PL.EXCL there with father=1SG
'We live there with my father.' $\{T x t\}$

(Campbell this volume)
b. Iēe.wí?.nī̄ nkw-eta=yu jî̄̄ tyá?ā
and.then PFV-wait.for=3SG.M O companion[s3] PRG-go.around=3sG.M
'And then, he waited for his companions with whom he was going around.' $\{$ Txt $\}$

(Campbell this volume)

Tlaxcala Nahuatl, with its non-configurational syntax (Flores Nájera 2019; this volume), allows for three possibilities: adpositional stranding (63a); pied-piping (63b); and the special pied-piping construction in (63c) that was characterized by Smith-Stark (1988) as 'piedpiping with inversion'. In (63c), the expected order of the configuration [ADPOSITION+REL.PRO] is inverted as [REL.PRO+ADPOSITION]. In this language, like in many others, relational nouns serve syntactically as heads of adpositional phrases.

TLaXcala Nahuatl (Uto-AzteCAN)
[tlen o-ni-mits-tsotson i-ka _ ]
WHICH PST-S1SG-PO2SG-hit.PFV POSS3SG-INSTR
'I threw the stick with which I hit you.'

(Flores Nájera this volume)

$\begin{array}{ll}\text { b. } \quad y=o-\emptyset \text {-wal-asi-ko } & \text { in } \\ \text { already=PST-S3-DIR-arrive-VEN.PST } & \text { DEF }\end{array}$

[i-nawa-k akin ti-mo-mik-ti-s-keh]

POSS3SG-side-LOC WHO S1PL-RR-die-CAUS-IRR-PL

'The coyote with whom we will fight got here.'

$\begin{array}{ll}\text { c. } y=o-\varnothing \text {-wal-asi-ko } & \text { in } \quad \frac{\text { koyo-tl }}{\text { already=PST-S3-DIR-arrive-VEN.PST }} \text { DEF }\end{array}$

(Flores Nájera this volume)

[akin i-nawa-k ti-mo-mik-ti-s-keh]

WHO POSS3SG-side-LOC S1PL-RR-die-CAUS-IRR-PL

'The coyote with whom we will fight got here.'

(Flores Nájera this volume) 
Pied-piping is, in general, a rare phenomenon in headed RCs in languages of Mesoamerica, but it is found. As pied-piping is typically associated with relative pronouns, its rarity can be readily accounted for as being due to the rarity of the former as a relativization strategy. It is more common in headless RCs (see Section 6 below). But when found, languages do not have the three possibilities like Tlaxcala Nahuatl. San Pedro Mixtepec Zapotec, for example, has RCS with adpositional stranding or pied-piping with inversion, as illustrated in (64). In some languages, pied-piping with inversion is only found in the relativization of a possessor, like in Tilapa Otomi (65).

$$
\text { San Pedro Mixtepec Zapotec (Zapotecan) }
$$
a. $y$-ǒ
[chò $b$-lŭ
Dè
$d i^{\prime} d z$
ló]
ST-exist WHO CP-show
D. word RN.FACE

'There's someone whom Delfino warned.'

(Antonio Ramos 2021: 246)
b. $y$-ǒ
[chò ló
$b-l u ̌$
Dèlfín di'dz]
ST-exist WHO RN.FACE CP-show
D. word
'There's someone whom Delfino warned.'

(Antonio Ramos 2021: 246)

TILAPA OTOMI (OTO-PAMEAN)
(65) ni
ni $\frac{k h a^{\prime} n i}{\operatorname{man}}$ to rú
'The man whose horse died.'

$\begin{array}{lll}\text { phani } & b i & \text { tyü] } \\ \text { horse } & \operatorname{PFV}[\mathrm{s3}] & \mathrm{SS} / \mathrm{die}\end{array}$

(Palancar this volume)

In contrast, as for pied-piping, Zoochina Zapotec only exhibits the non-inverted version, as shown in (66), with the relativization of a possessor and of a locative.

ZOOCHINA ZAPOTEC (ZAPOTECAN)

(66) a. blhé'ydà? bénénh? xhí'inènh' nhónh bdápè? bínhà̀?

\begin{tabular}{|c|c|c|c|}
\hline$b-I h e^{2} y+d=a^{?}$ & $\underline{b e ́ n e ́ ?}=n h \grave{a}^{?}$ & [xhí'ình=nhà? & nhó+nhà? \\
\hline CP-see=NOM1SG & person=DEF & PSSD.SOn=DEF & WHO \\
\hline CP-hit & $C L F_{P R O}=D E F$ & & \\
\hline
\end{tabular}

(López Nicolás this volume)

b. byèy lháshghénh ' ${ }^{w}$ ít gánh' $d x a ̂ z a^{2}$

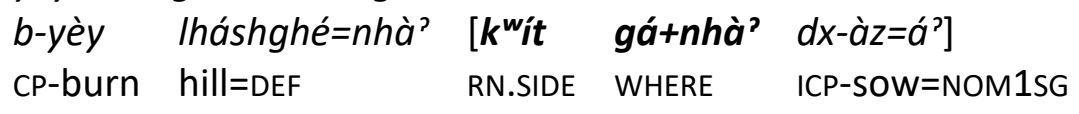

'The hill, on whose side I sow, was burned.'

(López Nicolás this volume)

In contrast, as suggested by Smith-Stark (1988), pied-piping with inversion is characteristic of the syntax of interrogatives and it is found in almost all the languages of the area, 
independently of the syntax of relativization. It is found, for example, in Zoochina Zapotec (contrast (67) with (66b)), in Jamiltepec Mixtec (compare (68) with the adposition stranding construction in (61) above), and in Q'anjob'al (example (69) interrogates a possessor). In some languages, pied-piping with inversion is only found in such circumstances, as shown in (70) from Tilapa Otomi.

ZOOCHINA ZAPOTEC (ZAPOTECAN)

(67) gă kwitènh'dxàzò?

gä $\quad k^{w}{ }^{i} t=n h \grave{a}^{?} \quad d x-\grave{a} z=\grave{o}^{?} ?$

WHERE RN.SIDE=FOC ICP-SOW=NOM2SG

'At what side do you sow?' $\{$ Txt $\}$

(López Nicolás this volume)

JAMILTEPEC MIXTEC (MIXTECAN)

(68) yóó chihín káhán ñii?

WHO with CP.speak she

'With whom is she speaking?'

(Johnson 1988: 41)

Q'ANJOB'AL (MAYAN)

(69) mach'a x-nich'an

bejk'aj?

WHO POss3-son.of.man be.born'

'Whose son was born?'

(Mateo Toledo this volume)

TILAPA OTOMI (ОtO-PAMEAN)

(70) to rú $\underline{u}$ ngü gú ${ }^{h}$ ta ?

WHO CLF.SG.POSS3 house PFV.S2 buy

'Whose house did you buy?'

(Lit. 'Who his house did you buy?')

(Palancar this volume)

These facts suggest that pied-piping with inversion is intrinsically a feature of the syntax of interrogation in Mesoamerican languages, which, given its wide spread in this linguistically diverse area and its typological oddity, could be claimed to be a genuine areal structural of Mesoamerica (Smith-Stark 1988). The syntax of RCS of specific languages may then mimic this construction, as is the case, for example, of San Pedro Mixtepec Zapotec in (64b) or Tilapa Otomi in (65).

At times, RCS may exhibit surface phenomena that could at first sight be taken as instances of pied-piping with inversion, when in reality they are not. This is the case with RCS with adjunct relativization like in Pajapan Nahuat (Nahuatl; Uto-Aztecan), as shown in (71). A comitative in this language is encoded obliquely in an adpositional phrase headed by the relational noun iwa: $n$, which functions as a preposition (71a). The RC in (71b) shows that when the domain nominal functions as a comitative participant in the RC, the preposition iwa:n occurs after yeh, a sequence of words which could give the impression of being piedpiping with inversion. However, the linking element yeh here is a subordinator and not a relative pronoun, so it occurs in its natural position in the clause and is not a complement of 
a pied-piped adpositional phrase. Evidence that yeh is a subordinator and not a relative pronoun is given in (72a) and (72b), where it is shown that yeh is not sensitive to features of the domain nominal. Example (72c) further shows that it introduces complement clauses. Instances like (71b) are RCs with a gap that exhibit a stranded adposition. The peculiarity of the construction reveals that the adposition, instead of occurring in situ, has moved to a higher position in the clause, right after the subordinator. This could be taken as a residue of the old non-configurationality of RC structure in Nahuatl languages.

Pajapan Nahuat (Uto-Aztecan)

a. ti-wa:lah [i-wa:n ho:n ta:ga-t]
S2-come.PFV POSS3-COM DEM man-ABS

'You came with that man.'

(Peralta Ramírez 2017)

b. a-ni-g-i:xmati ta:ga-t [yeh i-wa:n ti-wa:lah] NEG-S1-PO3-know man-ABS SUB POSS3-COM s2-come.PFV

'I don't know the man with whom you came.'

(Peralta Ramírez 2017)

PAJAPAN NAHUAt (UTO-AZTECAN)

(72) a. ni-g-ita-k se $\underline{\text { tago }}$ [yeh $\varnothing$-mo:nsah] S1-PO3-see-PFV INDF maiden SUB s3-be.beautiful

'I saw a maiden who was beautiful.'

(Peralta Ramírez 2017)

b. xi-neh-maga taxkal [yeh Ø-toto:nik] IMP-PO1-give tortilla SUB s3-be.hot

'Give me the tortilla that is hot.'

(Peralta Ramírez 2017)

c. aya: Ø-gi-mati [yeh yeh=san ompa o- $\varnothing$-pano:-k]

NEG s3-PO3-know SUB $3_{\text {PRO }}=$ just there PST-s3-pass-PFV

'He doesn't remember that he just passed by there.'

(Peralta Ramírez 2017)

\subsubsection{Relativized Functions and Relativization Strategy}

Languages may show meaningful correlations between relativization strategies and relativized functions. We have seen in Section 4.2, for example, that the relative pronoun strategy is found in all languages to relativize a locative, and that in some languages it is further found for subject (and possessor), etc. Sochiapam Chinantec (Chinantecan) is an interesting case of such correlations. In this language, the gap strategy can be used for the relativization of core functions. Here the determiner of the DP in which the domain nominal is embedded may either precede the RC (73a), or occur after it (73b).

Sochiapam CHINANTEC (ChINANTECAN)

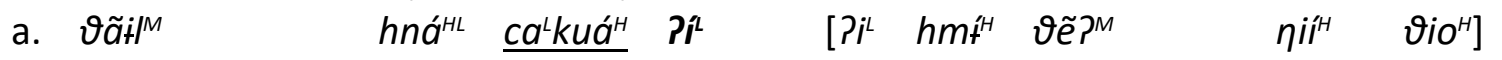

$$
\begin{aligned}
& \text { like.ST.T.AN.S1SG I horse that.AN SUB TERM stand.ST.I.AN place yonder }
\end{aligned}
$$


'I like that horse that was standing over there.'

(Foris 2000: 310)
b. $\vartheta \tilde{a} i^{M}$
$h n a^{H L} \quad \underline{c a}$
$\frac{c a^{2} k u a^{H}}{\text { horse }}$
$\left[\begin{array}{lll}P^{L} & h m t^{H} & \vartheta \tilde{e} ?^{M}\end{array}\right.$
$\eta$ ii $\left.^{H} \quad \vartheta_{i O^{H}}\right] \quad \mathbf{P i}^{\mathbf{L}}$
like.ST.T.AN.S1sG I
SUB TERM stand.ST.I.AN
place yonder that.AN
'I like that horse that was standing over there.'

(Foris 2000: 310)

The determiner in (73) agrees in animacy with the head noun. There is a second RC construction where the determiner occurs within the RC, shown in (74).

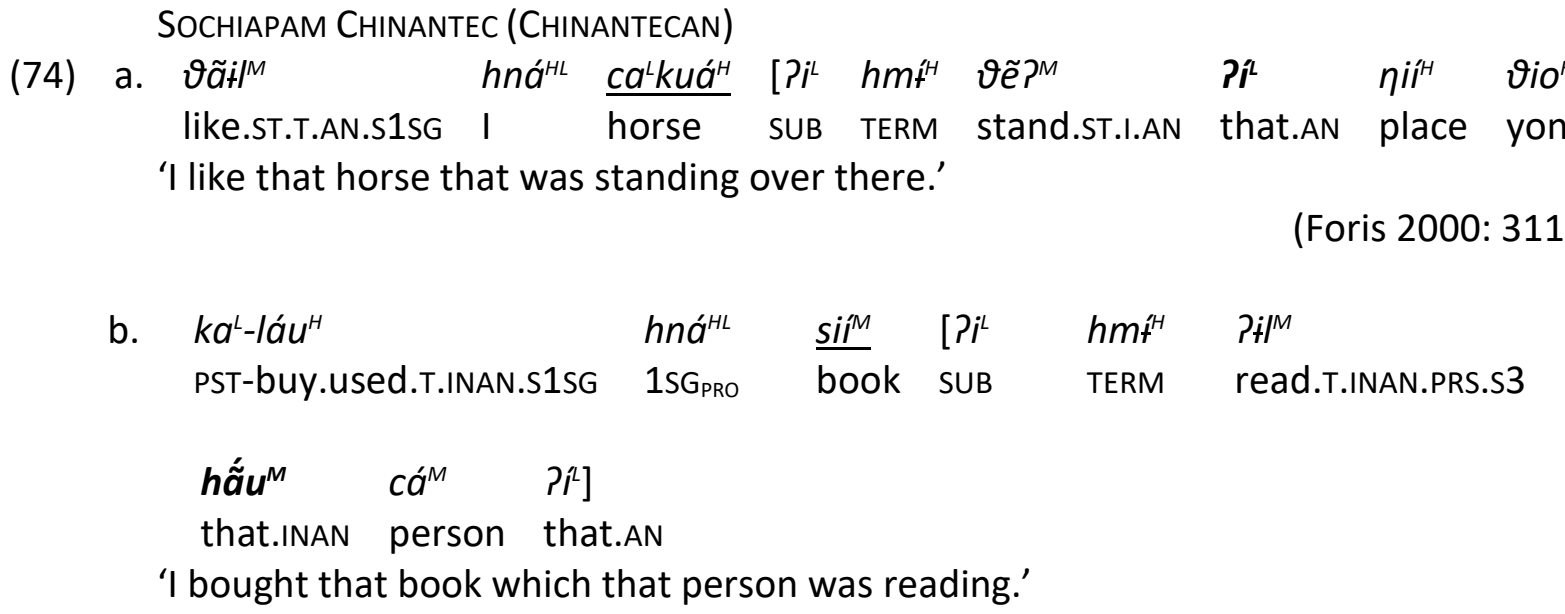

(Foris 2000: 312)

While determiners cannot be used pronominally elsewhere in the syntax, the fact that they occur inside the RC in constructions like these suggests the existence of some type of pronoun-retention relativization strategy. A somehow similar situation is found in San Miguel Chimalapa Zoque (Jiménez this volume) where we find RCs with internal determiners (see example (81b) further below). Alternatively, the construction in (74) could be interpreted as exhibiting a discontinuous DP, but there are strong arguments against such a non-configurational analysis. For one thing, the determiner - like other pronouns - must occur right after the predicate in a fixed position: it follows the subject pronoun if there is one (75a), and when the subject is encoded by a NP, the determiner always precedes it (75b).

SOCHIAPAM CHINANTEC (CHINANTECAN)

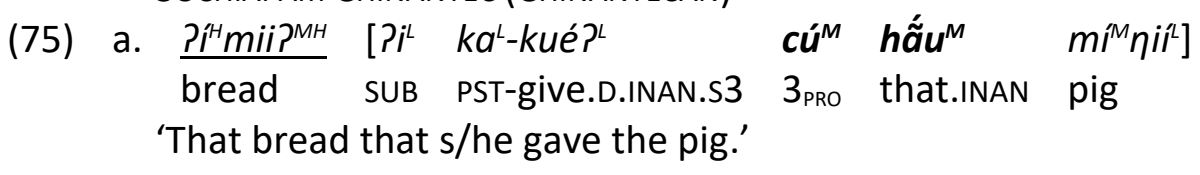

(Foris 2000: 314)

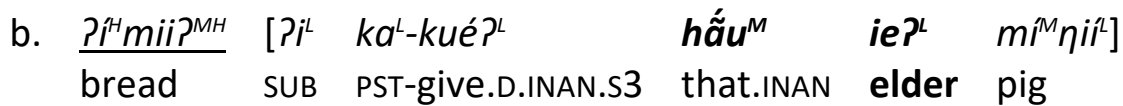
'That bread that the old man gave the pig.'

(Foris 2000: 314) 
As shown by the examples in (74) and (75), the pronoun-retention construction can be used to relativize a core argument, but it is not the preferred strategy for that specific function. The usage of the construction becomes more common as we move further down the relativization hierarchy to relativize other positions. For example, it is the preferred construction to relativize an instrument (76a), but it becomes the only strategy available to relativize a possessor (76b), where it would be ungrammatical not to use it. ${ }^{12}$

SOCHIAPAM CHINANTEC (CHINANTECAN)

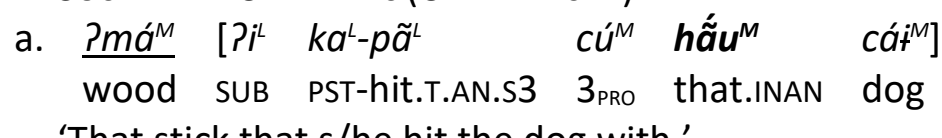

'That stick that $\mathrm{s} /$ he hit the dog with.'

(Foris 2000: 315)

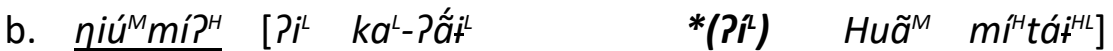
boy SUB PST-Steal.T.INAN.S3 that.AN J. machete
'That boy whose machete John stole.'

(Foris 2000: 315)

\subsection{Relative Clauses Not Headed by Nominals}

\subsubsection{Different Types of Heads}

A headed RC is a modifier of the domain nominal that serves as its head. In the canonical case, a domain nominal is a full noun that introduces an event participant in the matrix clause that serves as an argument or an adjunct. In contrast, headless RCS are RCS which serve as arguments or adjuncts in the matrix clause. As proposed in the vast literature on RCS (Keenan and Comrie 1977; Lehmann 1984, 1986; Comrie 1989; Kroeger 2005; Andrews 2007; inter alia), an important parameter to design a typology of RCS is categorizing RC constructions according to whether they are headed or headless, and if headed, by what type of head. In (77) we present the different possibilities.

(77) Headed RCs:

-RCs headed by an overt nominal (i.e., canonical headed RCS)

-RCS headed by an elided nominal

-RCS headed by a determiner

-RCs headed by a light head (a.k.a. "light-headed" RCS, Citko 2004)

Headless RCS

There are Mesoamerican languages whose RC constructions cover the full spectrum of the typology in (77). One such language is San Miguel Chimalapa Zoque (Jiménez this volume). An illustration of a RC headed by an elided nominal is given in (78). This type normally has the same distributional properties as RCs headed by an overt nominal.

San Miguel Chimalapa Zoque (Mixe-Zoquean)

\footnotetext{
12 This is further support for the typological claim by Lehmann (1986) that the relativization of the genitive phrase always displays idiosyncrasies. To this we can add the context for the interrogation of a possessor, which, as noted, requires pied-piping with inversion in all Mesoamerican languages.
} 
(78) 'ły nipłkwakxukkí jemji, 'ły 'angnitpa'

\begin{tabular}{|c|c|}
\hline$y=n i-p \dot{k}-w a k-x u k-w i$ & jemji _ \\
\hline 3A.I=body-grasp-split-3PL-CP.I & all \\
\hline
\end{tabular}

'They stole all (the gold) that he had.' $\{$ Txt $\}$

(Jiménez this volume)

A RC headed by a determiner is one where a determiner is the head of the RC. Generally, one could argue that RCS with a determiner are instances of a RC where the head nominal has been elided because it is topical, like in (79a) in Spanish, the argument being that one could restore the noun, as in (79b), with the only risk of the sentence becoming too informative.

(79) a. realmente es una oportunidad muy importante la __ [que vamos a tener]

'It's really an important opportunity, the one we're going to have.'

(Lit. 'Really is an important opportunity the (one) we're going to have.') \{Txt\}

b. realmente es una oportunidad muy importante la oportunidad [que vamos a tener] 'It's really an important opportunity, the opportunity we're going to have.'

However, in Spanish there are also instances of RCS with a determiner that do not readily stand for a specific topical noun mentioned in the previous discourse (whose referent may be readily recoverable either from the discourse or the context). Such examples appear to be instances of RCs headed by a determiner, like the proverb in 0 .

(80) el [que ríe el último] ríe mejor

'The one who laughs last, laughs best.'

(Lit. 'The (one) that laughs last, laughs best.')

We find a similar construction in San Miguel Chimalapa Zoque in (81a). However, contrary to what happens in Spanish, in this language there is strong evidence that the determiner serves as the head of the RC, because it can occur internal to the RC, like in (81b), which is structurally similar to examples with a full nominal head like (50) above, repeated here as (81c).

San Miguel Chimalapa Zoque (Mixe-Zoquean)

(81) a. kay mong bi 'ixtenoba'

$\begin{array}{llll}\text { kay } & \varnothing=\text { mong-wi } & \text { bi } & {\left[\varnothing==^{\prime} i x-\text { ten-'oy- } p a=p \dot{t}^{\prime}\right]} \\ \text { now } & \text { s3.I=sleep-ICP.I } & \text { DET } & \text { s3.I=see-stand-AP-ICP.I=REL }\end{array}$

'Now the one that is the sentinel fell asleep.' $\{$ Txt $\}$

(Jiménez this volume)

b. dey bi yiji witpa' piyukixoyyi

$\left[\right.$ tey bi $\left.y \dot{i}=j i \quad \varnothing=w i t-p a=p \dot{t}^{\prime}\right] \quad \emptyset=p i y u-k \dot{t} x-' o y-w \dot{t}$

nOW DET PROX=LOC s3.I=walk-ICP.I=REL s3.I=chicken-eat-AP-CP.I

'The one that is walking about here ate chicken.' $\{$ Txt $\}$

(Jiménez 2014: 353)

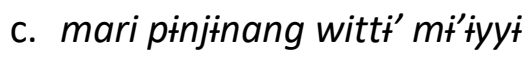


[Mari pin=jinang $\left.\varnothing=w i t-w \dot{t}=p \dot{t}^{\prime}\right] \quad \varnothing=m \dot{t}^{\prime}+y-w \dot{t}$

M. $\quad$ man=COM s3.I=walk-CP.I=REL s3.I=get.married-CP.I

'The man with whom María was involved got married.'

(Jiménez this volume)

There is a very thin line dividing RCs with a determiner in (81a) and (81b) from light-headed RCS. The difference between the two types lies in the fact that a light-headed RC involves a pronominal element as head. The pronominal element in question is often a demonstrative that can also serve as a determiner in nominal syntax (other elements such as quantifiers and numerals are also possible, Caponigro 2021). In a language where both constructions are found, such as San Miguel Chimalapa Zoque, they have an almost identical distribution (except for the relativization of reason, see Jiménez this volume).

\subsubsection{Free Relatives}

Besides the types presented in the previous section, in a broader typological perspective headless RCs typically involve relative pronouns. These relative pronouns are often recruited from WH-word paradigms, reflecting the great extent to which the syntax of relativization is tied to the syntax of focus by way of the syntax of interrogatives. When a headless RC is introduced by a WH-word relative pronoun, it is often referred to, in the typological literature, as a "free relative" (see Caponigro 2021).

Across Mesoamerican languages, except for the locative, the relative pronoun relativization strategy is typically only found in free relatives, at least in natural discourse. This is so to such an extent that in a language family like Mayan, relative pronouns are typically ONLY found in free relatives (except again for the locative; also the Tseltalan branch allows for a relative pronoun for humans in headed RCs); see Mateo Toledo (this volume) for a clear illustration of the phenomenon in $Q^{\prime}$ anjob'al). Free RCs are often constructed in such a way that there is also a subordinator introducing the RC. This is illustrated in Tseltal in $(82) \cdot{ }^{13}$

TSELTAL (MAYAN)

\begin{tabular}{|c|c|c|c|c|c|}
\hline$y$-ik'-otik & tel & [te & mach'a & ya & $x^{-}$'at'ej-otik=e] \\
\hline A3-call-Po1PL & DIR:come+NF & SUB & WHO & ICP & ICP.INTR-work-S1PL=DET \\
\hline
\end{tabular}

'He brings those of us that work.' $\{$ Txt $\}$

(Polian 2013: 793)

\subsubsection{Headless Relative Clauses with a Gap}

Apart from free relatives, in the Mesoamerican languages it is very common to have headless RCs with a gap. The following three languages, from different families, illustrate instances of headless RCs introduced by a subordinator.

TSELTAL (MAYAN)

(83) melel yak-otik s-nop-el away [te ch'in alal-otik=e]

true PRG-PO1PL A3-learn-NF.PASS EXPL SUB DIM child-S1PL=DET

'Those of us who were small were learning it.' $\{$ Txt $\}$

(Polian 2013: 792)

\footnotetext{
${ }^{13}$ The same construction can be found in headed RCs; see Campbell (this volume) for Zenzontepec Chatino or Hernández-Green (2021) for Acazulco Otomi.
} 
Sierra Popoluca (Mixe-ZoQuean)

(84) nuk'igatogoy

$\varnothing=n u k-w i \quad[$ iga $\varnothing=$ tokoy-wi]

s3=arrive-CP SUB s3=loss-CP

'The time of his death arrived.' $\{$ Txt $\}$

(López 2021: 506)

Zenzontepec Chatino (ZAPOtecan)

(85) yākwá tāká [nu nka-sup̄u tī j-nāąa] mastrū j-nāá?

there exist SUB PFV-teach TOP DAT-1SG teacher GEN-1SG

'There lives (the one) who taught me, my teacher.' $\{$ Txt $\}$

(Campbell this volume)

We also have cases of headless RCs introduced by relativizers, for example in Sierra Popoluca (Gulf Zoquean) in (86), Ocotepec Zoque (Chiapas Zoquean) in (87), and Matlatzinca (Otomian) in (88).

SierRa Popoluca (Mixe-ZoQuean)

(86) 'oyom 'i'a'myaj kuyujyajwi'ip

'oy-wi='am ' 'i='a'm-yaj-wi [

AUX.go-CP=already $A 3=$ see-3PL-CP $\quad s 3=$ study-3PL-CP=REL

'They already went to see those who studied.' $\{$ Txt $\}$

(López 2021: 505)

OCOTEPEC ZOQue (MIXE-ZOQueAn)

(87) tsyijkyaju tsa'bi

$y$-tsik-yaj-u $\quad[\varnothing$-tsa'=pi']

A3-make-PL3-CP S3-stone=REL

'They made what is made of stone.' $\{T x t\}$

(de la Cruz Morales 2016: 102)

MatLanzinca (Oto-PAMEAN)

(88) ga khwen hóhya [n gu khana pax-kwentu... ]

PRTCL ICP.S1PL forget REL ICP.S3SG well keep-talk

'And we forget about the one who has a good command of the language...' $\{$ Txt $\}$

(Palancar \& Carranza Martínez 2021: 168)

These examples show that the phenomenon is found in unrelated language families across Mesoamerica (e.g., Mayan, Mixe-Zoquean and Oto-Pamean), but it is even found in isolates like Purepecha, as shown in (89), which is a language that despite being spoken in the geographical and cultural area of Mesoamerica, in many other respects does not show the typical traits of a Mesoamerican language. This suggests that the phenomenon is widespread and common.

PUREPECHA (Isolate)

(89) pero [inki cha mia- $\left.\varnothing-\varnothing-k^{\prime} a\right]$, 
pero REL you remember-HAB-NON.PST-SBJV

ampe ka ampe cambiar-i-s- $\varnothing$-ki?

thing and thing change-PRED-PFV-NON.PST-INTER

'But of what you remember, what is it that you changed?' $\{$ Txt $\}$

(Hernández Domínguez 2015: 363)

In the same fashion, we also find instances of asyndetic headless RCs. This is illustrated in the following examples: (90) is from Q'anjobal (Mayan); (91-92) are from two Oto-Pamean languages, Matlatzinca and Tilapa Otomi, respectively. The interpretation of the role played by such headless RCs in the matrix clause relies on common sense and knowledge of the context. In Q'anjob'al asyndetic headless rcs can only be used as the argument of the existential predicate ay. The RCS in (91) and (92a) function as the subject of their matrix clause and in (92b) as the object. In (91a) and (92b), the subject is relativized, while in (91b) the object is relativized, and in (92a) the possessor.

Q'ANJOB'AL (MAYAN)

(90) ay- $\varnothing \quad\left[c h^{\prime}-\varnothing\right.$-ek'-el miman $\left.b^{\prime} e\right]$

EXIST-B3 POT-B3-pass-DIR big road

'There are (those) [spirits] that cross the big road.' $\{$ Txt $\}$

(Mateo Toledo this volume)

MatLANZINCA (Oto-PAMEAN)

(91) a. [me $n$ to meriu _suBs $]_{\text {subs }}$ tu táni $n$ to pari have CLF DIM money CP.3SG buy CLF DIM horse

'ix $n$ to burro

or CLF DIM donkey

'The one who has money buys a horse or a donkey.'

(Lit. 'Has money buys a horse or a donkey.') $\{$ Txt $\}$

(Palancar and Carranza Martínez 2021: 169)

b. kuh pëki [khwén pu=n pantí —o $]_{\mathrm{SUB}}$

CP.3SG be.a.lot ICP.1PL.EXCL there=LK gather

'There was a lot of what we used to gather up.'

(Lit. 'There was a lot we used to gather up.') $\{$ Txt $\}$

(Palancar and Carranza Martínez 2021: 169)

TILAPA OTOMI (OTO-PAMEAN)

(92) a. porke kha ti zo='ku=wi

because LOC.FOC PFV.IRR[S3] SS/arrive.there.AS=there=DU

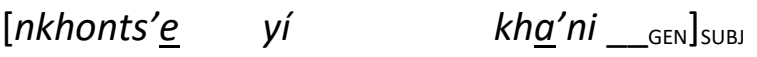

not.exist[S 3 ] DEF.PL.POSS3 person

'Because it's there where those who have no family end up.'

(Lit. '...(those whose) their family doesn't exist...') \{Txt\} 
(Palancar this volume)

b. [xpi etxaperder__uв $]_{\text {ов }} \quad t \underline{u}={ }^{\prime} u n y=a$

PFV go.off.food[So3] PFV.IRR.VEN>EXLOC[S3]=give[O3].AS=CL

'What had gone off (i.e., the gone-off food), he'd go and give to them.'

(Lit. '...(what) has gone off...') \{Txt

(Palancar this volume)

Asyndetic headless RCs like the ones in (90-92) are also found at the northern fringes in Cora, where the headless RC is introduced by the special set of subject pronominal clitics which only occur in a subordinated clause. An example of the construction is given in (93), with a topicalized headless RC that functions as the object of the matrix predicate.
(93) [meh tahkáy wá?a-u- $\left.k^{w} i:\right]_{\text {ов }}$ mu?u=rí wa-bá?ana S3PL[sub] yesterday PO3PL-CP-kill.PO/PL S3PL=already CP-bury
'The ones who had been killed yesterday, they have already buried them.'
(Lit. 'They killed them they bury them.')

(Vázquez Soto 2002: 294)

Furthermore, examples from Sierra Popoluca in (84-85) and from Matlatzinca in (88) and (91) illustrate the fact that within one particular language we can find different types of headless RCs with a gap. As a rule, the use of one construction over another directly correlates with the frequency of use of the construction as a headed Rc construction.

Headless RCS with a gap - syndetic (with a general subordinator or a relativizer) or asyndetic - represent a structural type that has not been identified in the typological literature. Mesoamerica is a linguistic area where headless RCS with a gap abound. One could ask how common they are in a given language when they are found, as one might equate typological rarity with discourse or systemic naturalness. However, the figures seem to suggest otherwise.

In a corpus study of the RCs in Wichmann's (1996) texts in Texistepec Popoluca (Gulf Zoquean; Mixe-Zoquean), Díez Alejandre (2019) finds that RCs with a relativizer, like the ones in 0 or 0 (which are cognate with other Zoquean languages) are by far the most common type of RC in this language (83\%). The relevant figures are given in Table 1.1.

\section{TABLE 1.1. Corpus-based distribution of types of RCs in Texistepec Popoluca}

\begin{tabular}{lrr} 
RC introduced by: & & \\
\hline REL & 224 & $\mathbf{8 3 \%}$ \\
SUB & 5 & $2 \%$ \\
Asyndetic & 5 & $2 \%$ \\
REL.PRO & 37 & $13 \%$ \\
\hline Total & 271 & $100 \%$ \\
\hline
\end{tabular}

Table 1.2 shows the distribution of the different types of RCS (headed, headless and lightheaded). More than half of the RCS (55\%) are headless. The figures suggest that RCs that are used as arguments or adjuncts in matrix clauses (headless RCS and light-headed RCS) are 
more common in the discourse than headed ones (i.e., headed RCs account for only $34 \%$ of the corpus).

TABLE 1.2. Corpus-based distribution of RCs in Texistepec Popoluca (per type)

\begin{tabular}{lrrrrrrrr}
\hline & \multicolumn{1}{c}{ Type of RC } \\
RC introduced by: & \multicolumn{1}{c}{ Headed } & \multicolumn{2}{c}{ Headless } & Light-headed & \multicolumn{2}{c}{ Total } \\
\hline REL & 78 & $35 \%$ & 122 & $54 \%$ & 24 & $11 \%$ & 224 & $100 \%$ \\
SUB & 5 & 100 & & & - & & 5 & $100 \%$ \\
& & $\%$ & & & & & & \\
Asyndetic & 4 & $80 \%$ & & & 1 & $20 \%$ & 5 & $100 \%$ \\
REL.PRO & 5 & $14 \%$ & 27 & $72 \%$ & 5 & $14 \%$ & 37 & $100 \%$ \\
\hline Total & 92 & $\mathbf{3 4} \%$ & 149 & $\mathbf{5 5 \%}$ & 30 & $11 \%$ & 271 & $100 \%$ \\
\hline
\end{tabular}

What is striking is the fact that headless RCs with a relativizer account for $82 \%$ of all headless RCS in the sample (with regard to free relatives), as indicated in Table 1.3. Even if the 30 light-headed RCS are taken into account, headless RCS with a relativizer would still amount to $68 \%$ of all RCS that function as arguments or adjuncts in matrix clauses. This means that a headless RC with a gap is far from being a structural oddity in the syntax of Texistepec Popoluca, but the most canonical headless RC structure in the minds of its speakers. We anticipate similar results in other Mesoamerican languages with comparable RC structures.

TABLE 1.3. Corpus-based distribution of RCs in Texistepec Popoluca (per function)

\begin{tabular}{lrrrrrrrr}
\hline & \multicolumn{10}{c}{ Type of RC } \\
RC introduced by: & \multicolumn{1}{c}{ Headed } & \multicolumn{2}{c}{ Headless } & \multicolumn{2}{c}{ Light-headed } & \multicolumn{2}{c}{ Total } \\
\hline REL & 78 & $85 \%$ & 122 & $\mathbf{8 2} \%$ & 24 & $80 \%$ & 224 & $83 \%$ \\
SUB & 5 & $5 \%$ & - & $0 \%$ & - & $0 \%$ & 5 & $2 \%$ \\
Asyndetic & 4 & $5 \%$ & - & $0 \%$ & 1 & $3 \%$ & 5 & $2 \%$ \\
REL.PRO & 5 & $5 \%$ & 27 & $18 \%$ & 5 & $17 \%$ & 37 & $13 \%$ \\
\hline Total & 92 & $100 \%$ & 149 & $100 \%$ & 30 & $100 \%$ & 271 & $100 \%$ \\
\hline
\end{tabular}

The picture we obtain for headless RCs in Mesoamerica drastically changes again when we consider language families at the outer borders of Mesoamerica, both to the north and to the south. In languages from such areas, headless RCs are encoded as nominalizations. This can be seen in (94) from Yaqui (Uto-Aztecan), a language from northern Mexico. Both examples in (94) illustrate relativization of an object, like in (2b) above, where the predicate of the RC must be marked by the nominalizer -' $u$, while the notional subject in the RC is casemarked as genitive. In example (94a), the nominalized RC is embedded in a DP headed by the determiner $u$, whereas in (94b) it is an NP. In (94a), the RC functions as the subject of the matrix clause and in (94b) as the object.

$$
\text { YAQUI (UTO-AZTECAN) }
$$

$$
\begin{array}{llll}
\text { a. } \left.\boldsymbol{u} \text { [itom nu'upa-ka-'u } \boldsymbol{u}_{\text {ов }}\right]_{\mathrm{SUBJ}} & \text { kaa jaleki } \\
\text { DET GEN1PL bring-PFV-O.RE } & \text { NEG enough } \\
\text { 'What we brought is not enough.' } &
\end{array}
$$



b. [in yaa-bae-' ов $\left._{\text {ов }}\right]_{\text {ов }}$ ne kopta-k GEN1SG do-DES-O.REL NOM1SG forget-PFV 'I forgot what I was going to do.'

Nominalized headless RCS are also found to the south of Mesoamerica, as seen in (95) from Pesh (Chibchan), a language from Honduras, where the RC (although internally finite) is casemarked with the role it plays in the matrix clause.
(95) a. kàpáfkúmà tàyè?í

$$
\begin{array}{ll}
{\left[k a p a f-k-\varnothing-w a=m a_{\text {SUB] }}\right]_{\text {SUBJ }}} & \text { ta-ye } ?=i \\
\text { speak-?-s3SG-PRS=NOM } & \text { POSS1-small=COP.PRS.S3SG }
\end{array}
$$
'The one who is speaking is my daughter.' $\{T x t\}$

b. fễherìrà kàrnāwĩ̀

(Chamoreau 2021: 541)

(Chamoreau 2021: 542)

\subsubsection{Headless Relative Clauses in Clefts}

We have shown that headless RCS function as arguments or adjuncts in matrix clauses. As part of that general function, headless RCS may also serve as complements of copular predicates in cleft constructions of the types shown in (96a) and (96b). Clefts are specialized focus structures that are biclausal by definition. They consist of a matrix clause (i.e., a specificational copular construction with a copular predicate, its subject phrase and its complement phrase) and a type of subordinate clause that encodes the background information in the cleft, and which is taken to be a headless RC at least from the typological perspective (see Drubig and Schaffer 2001). ${ }^{14}$

(96) a. It's Mary [who saw the cat] It-cleft

b. [Who saw the cat] was Mary Pseudo-cleft

The syntax of cleft constructions in the languages of Mesoamerica remains a largely understudied area. What we know so far seems to point in the direction of the canonical cleft in a Mesoamerican language having headless RCS with a gap. Two clear examples of clefts are given in the question-answer couplet in (97) from Ocotepec Zoque which instantiate the type of headless RC in (86) with a relativizer. Another example is (98) from Tseltal with a headless RC with a subordinator like the one in (83).

OCOTEPEC ZOQUe (MIXE-ZOQUEAN)

(97) a. tiyandeke ni mnhgä'subi'

\footnotetext{
${ }^{14}$ Such a view stems from Schachter (1973) and is continued in the pragmatic-syntactic approach in Lambrecht (2001).
} 


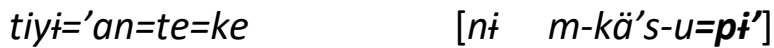

$$
\begin{aligned}
& \text { WHAT=alread } y=C O P=\text { then } \quad P R G \quad A 2 \text {-eat }-C P=R E L \\
& \text { 'What is it then that you're eating?' } \\
& \text { (Lit. 'What is then that you're eating?') \{Txt }
\end{aligned}
$$

(Ramírez Muñoz forthcoming)

b. ju'wi'te ni nhgä'subi'

$$
\begin{aligned}
& j u{ }^{\prime} w i=' t=t e \quad\left[n \dot{t} \quad n-k \ddot{a}^{\prime} s-u=p \dot{p}^{\prime}\right] \\
& \text { charcoal=ERG1=COP PRG A1-eat-CP=REL } \\
& \text { 'It's charcoal what I'm eating.' } \\
& \text { (Lit. 'Charcoal is that I'm eating.') }\{\text { TXT }\}
\end{aligned}
$$

(Ramírez Muñoz forthcoming)

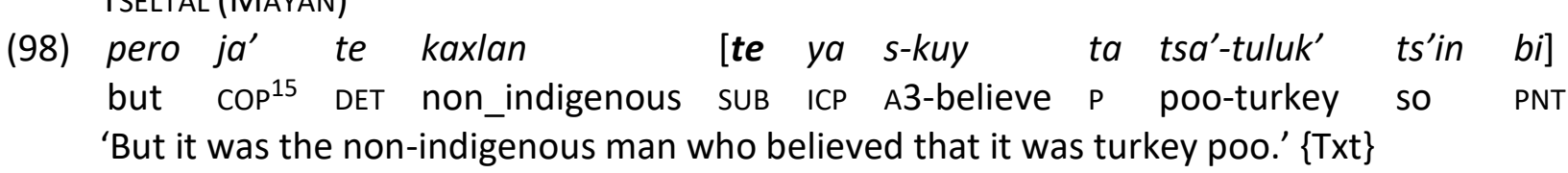

(Polian 2017)

Using the focus function of cleft constructions, speakers may manipulate the construction and convert it into a monoclausal focus structure (Zavala Maldonado 2017b). When this happens, the copula in the cleft is reanalyzed as a focus marker, and the structure no longer requires a headless RC. The contrast between the two focus structures is given in (99) from Ocotepec Zoque. Example (99a) is the monoclausal focus construction; example (99b) is a cleft. The two examples come from the same text, where one follows the other in the discourse, suggesting that speakers use both focus constructions at will to convey the same meaning with an equivalent pragmatic force.

\section{OCOTEPEC ZOQUe (MIXE-ZOQUEAN)}

(99) a. takujsti'unhnde pyijkyaju

$$
\begin{array}{ll}
\text { takus=ti='unh=te } \quad y-p+k-y a j-u \\
\text { walking.stick=just=REP=FOC } \quad \text { A3-grab-PL3-CP } \\
\text { 'They say they just grabbed a walking stick.' }\{\text { Txt }\}
\end{array}
$$

(Ramírez Muñoz forthcoming)

b. te'nade pyijkyajubi'

$$
\begin{array}{ll}
t e^{\prime}=n a=t e & {\left[y-p \dot{k} k-y a j-u=p \dot{y}^{\prime}\right]} \\
\mathrm{DEM}_{\mathrm{PRO}}=\text { only=COP } & \text { A3-grab-PL3-CP=REL }
\end{array}
$$

'It was only that what they grabbed.' $\{$ Txt $\}$

(Ramírez Muñoz forthcoming)

The string in (99a) pyäjkyaju 'they grabbed' is clearly NOT a headless RC in Ocotepec Zoque, because the language does not have asyndetic RCs. In this sense, the two focus constructions in (99) are formally very distinct. However, clefts become more difficult to spot in languages with asyndetic headless RCs. This is shown in Tilapa Otomi in (100), where the string grá

\footnotetext{
${ }^{15}$ Polian (2017) glosses $j a^{\prime}$ as a focus particle.
} 
ndegwi '(what) you (PL) want' that encodes the background in this construction looks like the string pyäjkyaju 'they grabbed' in (99a), that is, to the naked eye it does not look like a headless RC. ${ }^{16}$

\author{
TILAPA OTOMI (OTO-PAMEAN) \\ (100) $k e^{y} n=t s^{\prime} \underline{e}=a==^{\prime} a \quad$ [grá $\quad$ nde $={ }^{g}$ wi] $\approx^{\prime a} a$ ? \\ COP.AS=just $=C L=3 S G_{\text {PRO }} \quad$ IPFV.S2 want $=[S] P L \approx 3 S G_{\text {PRO }}$ \\ 'Is it just that what you (PL) want?' $\{T x t\}$
}

(Palancar 2018: 119)

However, the construction in (100) is a cleft containing the same type of asyndetic headless RC we find in examples like (92) above. Further proof of the RC status of (100) is given in the examples in (101). Example (101a) shows that in clefts, just like in other types of matrix clauses, locative headless RCS have to be introduced by a relative pronoun. In turn, example (101b) shows that the predicate of a headless RC exhibiting relativization of an instrument must also carry a special inflection (see Palancar (this volume) for more details).

\title{
TILAPA OTOMI (OTO-PAMEAN)
}

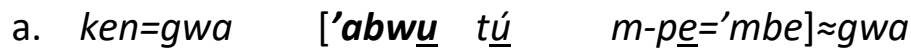

$$
\begin{aligned}
& \text { COP.AS=here WHERE PFV.S1 AP-Work.AS=PL.EXCL } \approx \text { here } \\
& \text { 'It's here where we worked.' }\{\text { Txt }\}
\end{aligned}
$$

(Palancar 2018: 120)

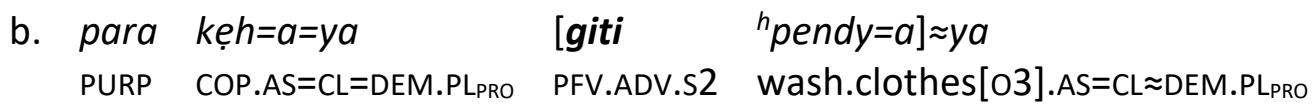

'So that it's these things you'll wash it with.' $\{$ Txt $\}$

(Palancar 2018: 122)

\subsection{Conclusion}

In this chapter, we have outlined what constitutes the canonical profile of RC structure in Mesoamerican languages. We have shown that the typical Mesoamerican RC is a morphosyntactic finite RC with a gap. When the relativized position is that of a locative, a relative pronoun is used; this pattern extends beyond Mesoamerica. In our proposal, we have so far identified three structural traits that we take to be Mesoamerican: (i) RCS introduced by determiners which agree in deixis with the DP in which the domain nominal is embedded of the headed RC; (ii) the so-called 'pied-piping with inversion', introduced by Smith-Stark (1988) for interrogatives, that has percolated into RC structure; and (iii) headless RCS with a gap. To our knowledge, our study is the first typological overview of RC structure in Mesoamerican languages and was only made possible thanks to a number of recent highquality studies in individual languages. This is just the beginning of our quest for a deeper

\footnotetext{
16 The subject of the copula in examples (100-101) is pronominal and it is realized by a pronominal enclitic associated with and hosted on the copular predicate. In canonical instances of the copular construction like these, there is a copy of that pronominal at the right edge of the matrix clause. That clitic is phonologically hosted on the last word of the clause, but it is not morphosyntactically associated with its phonological host, hence the use of the special symbol $\approx$ (see Palancar this volume).
} 
understanding of this fascinating area of the syntax of the indigenous languages of Mexico and Central America. Much remains to be done, and so our hope is that others will follow.

\section{BIBLIOGRAPHY}

Adamou, Evangelia \& Denis Costaouec. 2013. El complementante la en ixcateco: marcador de cláusula relativa, completiva y adverbial, Amerindia 31: 193-210.

Álvarez-González, Albert. 2012. Relative clauses and nominalizations in Yaqui. In Bernard Comrie and Zarina Estrada-Fernández (eds.), Relative clauses in Languages of the Americas. A typological overview. [Typological Studies in Language, 102], 67-96. Amsterdam: John Benjamins.

Andrews, Avery D. 2007. Relative clauses. In Timothy Shopen (ed.), Language typology and syntactic description, 206-236. Cambridge: Cambridge University Press.

Antonio Ramos, Pafnuncio. 2021. Headless relative clauses in San Pedro Mixtepec Zapotec. In Ivano Caponigro, Harold Torrence \& Roberto Zavala (eds.), Headless relative clauses in Mesoamerican languages, 221-259. New York: Oxford University Press.

Beck, David. 2016. Rcs in Upper Necaxa Totonac: Local, comparative, and diachronic perspectives, Linguistic Discovery 14: 1-45.

Boudreault, Lynda J. de Jong. 2009. A Grammar of Sierra Popoluca (Soteapanec, a MixeZoquean Language). PhD Dissertation. University of Texas at Austin.

Campbell, Lyle, Terrence Kaufman y Thomas C. Smith-Stark. 1986. MesoAmerica as a linguistic area, Language 92: 530-70.

Caponigro, Ivano. 2021. Introducing headless relative clauses and the findings from Mesoamerican languages. In Ivano Caponigro, Harold Torrence, \& Roberto Zavala Maldonado (eds.), Headless relative clauses in Mesoamerican languages, 1-57. New York: Oxford University Press.

Caponigro, Ivano, Harold Torrence and Carlos Cisneros. 2013. Free relative clauses in two Mixtec languages, International Journal of American Linguistics 79(1): 61-96.

Caponigro, Ivano; Harold Torrence \& Roberto Zavala Maldonado (eds.). 2021. Headless relative clauses in the Mesoamerican languages. Oxford: Oxford University Press.

Chamoreau, Claudine. 2019. Grammaticalization of the linking devices with $k a$ in Purepecha. In: Albert Alvarez González, Zarina Estrada Fernández \& Claudine Chamoreau (eds), Diverse Scenarios of Syntactic Complexity, 139-166. Amsterdam/Philadelphia: John Benjamins.

2020. Headless relative clauses in Pesh. In Ivano Caponigro, Harold Torrence, \& Roberto Zavala Maldonado (eds.), Headless relative clauses in Mesoamerican languages, 509-546. New York: Oxford University Press.

Citko, Barbara. 2004. On headed, headless, and light-headed relatives, Natural Language and Linguistic Theory 22: 95-126.

Comrie, Bernard. 1989. Language universal and linguistic typology: Syntax and morphology, 2nd edition. Chicago: University of Chicago Press. . 2003. What has linguistics learned from typology? Lingue e Linguaggio 2: 299-319.

Comrie, Bernard and Tania Kuteva. 2005. Relativization Strategies, in Martin Haspelmath, Matthew S. Dryer, David Gil, and Bernard Comrie (eds.), The World Atlas of Language Structures - WALS, 494-501. Oxford: Oxford University Press.

Cruz, de la, Morales, Román. 2016. Construcciones con predicados seriales en zoque de Ocotepec, Chiapas: Estructura, semántica y gramaticalización. MA Thesis in Indoamerican Linguistics. CIESAS, México. 
Dayley, Jon P. 1981. Voice and Ergativity in Mayan Languages, Journal of Mayan Linguistics 2: 3-82.

. 1990. Voz y Ergatividad en Idiomas Mayas. In Nora England and Stephen Elliot (eds.). Lecturas sobre la Lingüística Maya, 335-398. Guatemala: CIRMA.

Díez Alejandre, Álvaro. 2019. Les relatives en popoluca de Texistepec. MA Thesis. Université Paris Sorbonne Nouvelle.

Drubig, Hans-Bernhard and W. Schaffer. 2001. Focus constructions. In Martin Haspelmath, Ekkehard Koenig, and Wulf Osterreicher (eds.), Language Typology and Language Universals, 1079-1104. Berlin: Mouton de Gruyter.

Dryer, Matthew S. 2007. Word order. In Timothy Shopen (ed.), Languaje typology and syntactic description Vol. 1, pp. 61-131. Cambridge: Cambridge University Press.

Flores Nájera, Lucero. 2019. La gramática de la cláusula simple en el náhuatl de Tlaxcala. PhD Dissertation. CIESAS, México.

. 2021. Headless relative clauses in Tlaxcala Nahuatl. In Ivano Caponigro, Harold Torrence \& Roberto Zavala (eds.). Headless relative clauses in Mesoamerican languages, 79-110. New York: Oxford University Press.

Foris, David Paul. 2000. A grammar of Sochiapan Chinantec, [Studies in Chinantec Languages 6]. Summer Linguistics Institute and University of Texas at Arlington.

Fuß, Eric. 2005. The rise of agreement: A formal approach to the syntax and grammaticalization of verbal inflection. Amsterdam: John Benjamins.

Greenberg, Joseph H. 1963. Some universals of grammar, with particular reference to the order of meaningful elements. In Joseph Greenberg (ed.), Universals of Language. Cambridge, Mass: MIT Press.

Guarcax González, José Celestino. 2016. Las cláusulas relativas en el kaqchikel de Sololá. MA Thesis in Indoamerican Linguistics. CIESAS, México.

Hernández Domínguez, Rolando. 2015. Na-kani-ne jucha anapu jimpo: aspecto, tiempo, modalidad y modo en purépecha. PhD Dissertation. CIESAS, México.

Hernández-Green, Nestor. 2021. Headless relative clauses in Acazulco Otomi. In Ivano Caponigro, Harold Torrence \& Roberto Zavala (eds.), Headless relative clauses in Mesoamerican languages, 111-144. New York: Oxford University Press.

Jiménez Jiménez, Silviano. 2014. Esbozo gramatical y oraciones de relativo en el zoque de San Miguel Chimalapa. MA Thesis in Indoamerican Linguistics. CIESAS, México.

Johnson, Audrey F. 1988. A syntactic sketch of Jamiltepec Mixtec. In C. Henry Bradley and Barbara E. Hollenbach (eds.), Studies in the syntax of Mixtecan languages 1, 11-150. Summer Linguistics Institute and the University of Texas at Arlington.

Keenan, Edward and Bernard Comrie. 1977. Noun phrase accessibility and universal grammar, Linguistic Inquiry 8: 63-100.

Kroeger, Paul R. 2005. Analyzing grammar. An introduction. Cambridge: Cambridge University Press.

Lambrecht, Knud. 2001. A framework for the analysis of cleft constructions, Linguistics 39(3): 463-516.

Lastra, Yolanda. 2018. Textos chichimecos: Bosquejo gramatical, léxico y notas históricas. Volume I. Mexico City: Instituto de Investigaciones Antropológicas \& Universidad Nacional Autónoma de México.

Lehmann, Christian. 1984. Progress in general comparative linguistics, Studies in Language 8: 259-286.

. 1986. On the typology of relative clauses, Linguistics 24: 663-680. 
López, Wendy. 2021. Headless relative clauses in Sierra Popoluca. In Ivano Caponigro, Harold Torrence \& Roberto Zavala (eds.), Headless relative clauses in Mesoamerican languages, 475-508. New York: Oxford University Press.

Martínez Cruz, Victoriano. 2007. Los adjetivos y conceptos de propiedad en chol. MA Thesis in Indoamerican Linguistics. CIESAS, México.

Palancar, Enrique L. 2018. Clefts in otomi: Extended uses of the copular construction, International Journal of American Linguistics 84: 93-145.

Palancar, Enrique L. \& Leonardo Carranza Martínez. 2021. Headless relative clauses in Matlatzinca. In Ivano Caponigro, Harold Torrence \& Roberto Zavala (eds.), Headless relative clauses in Mesoamerican languages, 145-176. New York: Oxford University Press.

Peralta Ramírez, Valentin. 2017. Las cláusulas relativas sin núcleo en el nawat de Pajapan, Veracruz. Paper read at the 1st Workshop on Headless Relative Clauses in Mesoamerican languages. CIESAS, San Cristóbal de las Casas, Mexico, 27/11 -01/12.

Polian, Gilles. 2013. Gramática del tseltal de Oxchuc. México City: CIESAS. . 2017. Ecuativas y focalización en tseltal. Paper read at the Workshop on focus in Mesoamerican languages. CIESAS, San Cristóbal de las Casas, Mexico, 17-28/04.

Polian, Gilles \& Judith Aissen. 2021. Headless relative clauses in Tseltalan. In Ivano Caponigro, Harold Torrence \& Roberto Zavala (eds.), Headless relative clauses in Mesoamerican languages, 403-443. New York: Oxford University Press.

Ramírez Muñoz, Ernesto. 2016. Oraciones de complemento en el zoque de Ocotepec, Chiapas. MA Thesis in Indoamerican Linguistics. CIESAS, México.

. Forthcoming. El rayo ciego: un relato en zoque de Ocotepec, Tlalocan. Instituto de Investigaciones Filológicas, Universidad Nacional Autónoma de México.

Ramírez Pérez, Elodia. 2014. La predicación no verbal y las construcciones copulares en el tnu' $u^{23}$ dau $^{23}$ de Santa María Peñoles, Etla, Oaxaca. MA Thesis in Indoamerican Linguistics. CIESAS, Mexico.

Santiago Martínez, Godofredo G. 2015. Temas de fonología y morfosintaxis del mixe de Tamazulápam, Oaxaca. PhD Dissertation. CIESAS, Mexico.

Schachter, Paul. 1973. Focus and relativization, Language 49(1): 20-46.

Smith-Stark, Thomas. 1988. Pied-piping con inversión en preguntas parciales en lenguas de Mesoamérica. MS

Stiebels, Barbara. 2006. Agent Focus in Mayan Languages, Natural Language and Linguistic Theory 24: 501-570.

Tuggy, David H. 1979. Tetelcingo nahuatl. In Ronald Langacker (ed.), Studies in Uto-Aztecan grammar, 1-140. Arlington, University of Texas.

Vázquez Álvarez, Juan Jesús. 2011. A grammar of Chol, a Mayan language. PhD Dissertation. University of Texas, Austin, TX.

Vázquez Álvarez, Juan Jesús \& Jessica Coon. 2021. Headless relative clauses in Chol. In Ivano Caponigro, Harold Torrence \& Roberto Zavala (eds.), Headless relative clauses in Mesoamerican languages, 362-402. New York: Oxford University Press.

Vázquez-Soto, Verónica. 2002. Cláusulas relativas en cora meseño, in Paulette Levy (ed.), Del cora al maya yucateco: Estudios lingüísticos sobre algunas lenguas indígenas mexicanas. Mexico City: Instituto de Investigaciones Filológicas, Universidad Nacional Autónoma de México.

Velleman, Leah Bridges. 2014. Focus and movement in a variety of K'ichee'. PhD Dissertation. The University of Texas at Austin. 
Wichmann, Søren. 1996. Cuentos y Colorados en Popoluca de Texistepec. Copenhagen: C. A. Reitzels.

Zavala Maldonado, Roberto. 2017a. Alignment patterns. In Judith Aissen, Nora England, and Roberto Zavala Maldonado (eds.), The Mayan Languages, 226-258. London: Routledge, pp. 226-258.

. 2017b. Dos cadenas de gramaticalización de los demostrativos en oluteco. Paper given at CILLA VIII. Auxtin, Texas. October. 